\title{
Trubarjeva Hišna postila (1595) v odnosu do Lutrove prevodne predloge
}

\author{
Majda Merše
}

Prispevek je namenjen analizi Trubarjeve prevajalske tehnike v Hišni postili, ki je njegov najobsežnejši prevod, hkrati pa tudi njegova zadnja knjiga (izšla je leta 1595). Ker je Trubar prevajal Lutrovo postilo, sta bili v prevodnem razmerju nemščina in slovenščina 16. stoletja. V prispevku so naštete najopaznejše prevodne razlike, ki jih je deloma povzročila različnost jezikov, deloma pa so posledica različno motivirane Trubarjeve izbire.

Ključne besede: slovenski jezik 16. stoletja, Martin Luther: Hauspostill, Primož Trubar: Hišna postilla, prevodoslovje

\section{Trubar's Hišna postila in relation to Luther's original}

This article analyzes Trubar's translation technique in his Hišna postila (Devotions for the Home), which was his most extensive translation as well as his last book (published in 1595). Because Trubar was translating Luther's Hauspostill, the translation relationship involved sixteenth-century German and Slovenian. The article lists the most apparent translation differences, which are partly due to language differences and partly due to Trubar's variously motivated choices.

Key words: sixteenth-century Slovenian, Martin Luther's Hauspostill, Primož Trubar's Hišna postila

0 Razlike, ki jih odkriva primerjava Trubarjevega prevoda (TPo 1595) Lutrovega dela Haußpoftill in nemške prevodne predloge (LH 1566), ${ }^{1}$ so - kot je že bilo omenjeno pri raziskavah prevodne odvisnosti - predvsem dveh vrst: a) povzroča jih različnost jezikov in b) so rezultat prevajalčevega hotenega oddaljevanja od prevodne predloge. ${ }^{2}$

1 Uporabljena je bila izdaja iz leta 1566, ki je dostopna v Semeniški knjižnici v Ljubljani (Martin Luther, Haußpoftill, Nürnberg, 1566; LH 1566), za dodatno preverjanje pa na spletu dostopni posnetek izdaje iz leta 1544 (Martin Luther, Hauspostill, Wittenberg, 1544, Bayerische Staatsbibliothek, Münchener Digitalisierungszentrum, Digitale Bibliothek; LH 1544).

2 Besedili je v posebni razpravi primerjal J. Raecke (1995). Obravnave se je lotil z namenom, da bi ugotovil vzroke za (v uvodu zapisano) mnenje Trubarjevega sina Felicijana, ki je poskrbel za izdajo očetovega prevoda, da gre za »težko delo« (»er sich des schwären Wercks in die Windische Sprach zu vbersetzen vnderfangen «). Raecke je na osnovi izbranih odlomkov primerjalno ugotavljal Trubarjeve oddaljitve od nemške prevodne pre- 
- 1 Med najvidnejše razlike spadajo prevodne razširitve, ki so bile večinoma [ㄱ opravljene $\mathrm{z}$ namenom, da bi bil prevod razumljiv in da bi bila sporočana vsebina

1.1 Med razširitvami so pogostnostno v ospredju (že opaženi) sopomenski pari ter veččlenski naštevalni nizi. ${ }^{4}$

1.1.1 Značilna situacija, ki izziva pripis sopomenke, je prevzem v predlogi uporabljenega, manj znanega (npr. ajžel, haufen, muzika itd.), neredko celo prvega zapisa poimenovanja (npr. ahla, patrem, rajža, rumorati itd.5), ki potrebuje bolj znano ali v primeru večpomenskosti pomensko določnejšo sopomensko osvetlitev. ${ }^{6}$ Slednja je lahko domačega ali tujega izvora, predpogoj pa je, da je bralcu poznana in pomensko predstavljiva. Npr.: 1. Es ift ein eben weite reife von Nazareth auß Galilea / gen Bethlehem (LH 1566: I,XIX) - Onu je reis ena dolga raifha ali pot od Nazareta is Galilee, vBetlehem (TPo 1595: I,30); 2. Aber Gott füret ${ }^{7}$ Sein regiment alfo (LH 1566: I,XVIIIb) - Ampak Bug pela fvoj Regiment ali regirainje taku (TPo 1595: I,30); 3. da man im Patrem dife wort gefungen ftanden (LH 1566: I,XIXb) - kadar

dloge in jih analiziral tudi glede na možnosti sledenja originalu, ki jih je med drugim odpirala tedanja razvojna stopnja slovenščine. O prevodnem zrcaljenju razmerja med jezikovno pogojeno sistemskostjo in individualno ustvarjalnostjo v Dalmatinovem prevodu Biblije prim. Merše 1995.

3 Razmišljanje o Trubarjevem načinu prevajanja je tudi M. Stanovnik pripeljalo do ugotovitve, da je bil njegov besedni izbor premišljen, opravljen z namenom, da bi bilo bralcu omogočeno neovirano razumevanje prevajanega besedila. Avtorica je poleg prizadevanja za razumljivost izpostavila še dve temeljni značilnosti Trubarjevega prevodnega dela: zvestobo prevodni predlogi in številnost elementov literarne retorike (Stanovnik 2005: 39-40).

$4 \mathrm{O}$ t. i. dvojnih in trojnih formulah kot ustaljenem stilnem sredstvu v Trubarjevem jeziku govori B. Pogorelec (1972: zlasti 311-313), o različnih poimenovanjih istega pojava (npr. »dvojična prirednost«; Seitz 1995: 474) in o pojavu samem v Trubarjevih delih pa E. Seitz (1995; 1998: 109-152). E. Seitz je stilem raziskovala v Trubarjevih besedilih (slovenski in nemški predgovori k novozaveznim prevodom ter slovensko pismo deželnim stanovom iz leta 1579), v izvirnih besedilih Trubarjevih sodobnikov (Pogrebni govor Jakoba Andreaeja, Ungnadovo pismo, naslovljeno na nemške stanove in mesta, Dalmatinov nemški in slovenski uvod v Biblijo iz leta 1584), za primerjavo pa je uporabila Lutrove predgovore in pisma ter nekaj latinskih besedil (vse v raziskovani dolžini 2500 besed). Avtorica pri dvojični prirednosti glede na pomen razlikuje sopomenske, protipomenske, neodvisne in dopolnjevalne pare (Seitz 1995: 482). Pregled dosedanjih obravnav dvojne formule kot osrednjega retoričnega stilnega sredstva $\mathrm{v}$ jeziku slovenskih protestantskih piscev 16. stoletja je $\mathrm{v}$ okviru prikaza retorične oblikovanosti njihovih besedil prispeval K. Ahačič (2007: 297-313, zlasti 302).

5 O besednozakladnem prispevku postil (zlasti Trubarjeve Hišne postile ter Kreljevega in Juričičevega prevoda postile (1567 in 1578)) v okviru slovenskega knjižnega jezika druge polovice 16. stoletja prim. Merše 2007.

6 E. Seitz (1995: 477) ob povzemanju ugotovitev raziskovanja prevodne problematike izpostavlja uporabo dvojnih formul v primeru nenatančno prevedljivih pojmov.

7 Preglasi so označeni na danes uveljavljeni način. 
So vtim Patrem ali Vueri pejli, lete befséde (TPo 1595: I,31); 4. kommen vil taufent andere Engel / vnd heben ein fchöne Mufica an (LH 1566: I,XXVIb) - pridejo veliku taushent drugih Angelou, inu sazhneio eno leipo Mufico ali pejtje (TPo 1595: I,43); 5. ein ftinckend heimlich gemach des Teuffels (LH 1566: I,XXI) - en fmerdezh aifhel ali ferylnik tiga Hudizha (TPo 1595: I,34); 6. Der meyfte hauffe fuchet ein andere freude (LH 1566: I,XXIIIb) - Ta veg/hi haufen ali kardellu ${ }^{8}$ yfzhe eniga drugiga vefselja (TPo 1595: I,38); 7. Die wöllen jrer perfon halben fo from fein / das fie für Gottes gericht tretten dörfen / vnd [...] mit dem tod / mit der fünd vnd Teuffel fechten (LH 1566: II,Vb) - Ty hote sa fvoje Perfone ftran taku brumni biti, de pred Boshjo Praudo ali sodbo fmejo ftopiti, inu [...] sto Smertjo, Stem greihom, inu s'Hudizhom fe fehtati inu bojovati (TPo 1595: II,7); ${ }^{9} 8$. Gott rumore vnter denen / die jn nicht förchten (LH 1566: III,LXXXb) - Bug rumora ali fe ferdy s'témi, kateri fe njega boye (TPo 1595: III,137); 9. vnnd die gewaltigen heyffet man gnedige Herren (LH 1566: III,LXXXIIb) - ty oblaftniki bodo gnadliui ali miloftivi gofpudje imenovani (TPo 1595: III,141). ${ }^{10}$ Navedeni zgledi kažejo, da so pari, ki jih povezujeta veznika inu in ali, vsebinsko in tvorbeno različni. Med besednovrstno različnimi sopomenskimi pari prevladujejo samostalniški. ${ }^{11}$ Pogostnostno jim sledijo glagolske sopomenske dvojice, drugovrstne (npr. pridevniške) pa številčno močno zaostajajo. V 5. zgledu je s samostalniškima ustreznicama nadomeščeno evfemistično besednozvezno poimenovanje. S ponavljanjem istih parov znotraj postile je Trubar utrjeval razlagalno prakso, hkrati pa preverjal pravilnost izbire členov.

(1) V Trubarjevem prevodu je razširitev v dvojno formulo možno opazovati tudi v primeru uporabe dobro znanih in uveljavljenih prevzetih izrazov, kar kaže predvsem na stilno izrabo strukture. Npr.: 1. Da es nun vngefehrlich drey ftund auff den tag geweft [...] vnnd er zum gericht außgefüret worden / vnd gecreutziget (LH 1566: II,IIa-b) - Kadar je vfhe okulli tretje ure do dne bilu [...] je k'rihti inu kmartri vun pelan inu krishan bil (TPo 1595: II,1); 2. der [...] bochet drauff (LH 1566:

8 V TPo 1595 sta oba samostalnika pogosto rabljena (haufen $66 \times$, krdelo 56×). Sedemkrat se pojavljata $\mathrm{v}$ paru: šestkrat z običajno razvrstitvijo, to je prevzeti samostalnik + domače pojasnilo, enkrat pa v obrnjenem zaporedju.

9 Številčno razmerje med členoma glagolskega sopomenskega para v TPo 1595 je naslednje: fehtati se se pojavlja štirikrat - dvakrat v zvezi z bojovati (povezano z inu in ali) -, bojovati se pa šestkrat. Domačemu glagolu zagotavljajo številčno premoč sopomenske rabe variante brez se (npr. Satiga volo, de je on ta Mezh vroko vsel, inu hotel bojovati, je on krivu fturil (TPo 1595: I,235)). Prim. Merše - Novak - Premk 2001: 46-48.

${ }^{10}$ Raecke je ob primerjavi izbranega odlomka iz TPo 1595 z Lutrovo prevodno predlogo odkrival razlike, med katerimi so izstopali »dodatki« (npr. zeychen $\rightarrow$ Zaihne ali snameinja), ob njih pa t. i. »freie[n] Übertragungen« (Raecke 1995: 406-412).

${ }^{11} \mathrm{O}$ dvo- in veččlenskih samostalniških nizih ter samostalniških sopomenskih parih znotraj različnih pomenskih skupin pri slovenskih protestantskih piscih 16. stoletja prim. Novak 2004: 208-213. Avtor ugotavlja, da je pri sopomenkah pomenska stran potisnjena v ozadje, v ospredju pa je njihova izrazna učinkovitost (Novak 2004: 211-212). O sopomenskih parih v Trubarjevem jeziku, sestavljenih iz domačega in prevzetega poimenovanja, prim. tudi Rigler 1968: 98. 
III,LXXIX) - na tuiftu fhuga inu truza (TPo 1595: III,135). ${ }^{12}$ Omembe vredni so tudi pari, ki jih je Trubar prenašal v svoj prevod, ker so že bili del dotedanje knjižnojezikovne prakse: das wir dem Teuffel entlauffen / von fünden frey vnd ledig worden find (LH 1566: I,XXVIIb) - de my timu Hudizhu vbeifhimo, inu od grejhou fray inu ledig poftanimo (TPo 1595: I,45). ${ }^{13}$

(1a) Primere, kjer dobro znanemu in uveljavljenemu prevzetemu poimenovanju sledi prav tako znana domača sopomenka, si je mogoče razlagati tudi kot iskanje nadomestnih izraznih možnosti, s katerimi se odpira pot izbire, istočasno pa tudi kot utrjevanje sopomenskih povezav.

Vzrok za razširitev je lahko bilo tudi Trubarjevo prepričanje, da bi zgolj prevodno ohranjanje prevzetega samostalnika, uporabljenega $\mathrm{v}$ manj znani povezavi (npr. v prilastkovni zvezi), ne zadoščalo za jasno predstavo. Npr.: Alfo fihet man / $d z$ diß trawrbild nit lang bleibt (LH 1566: II,III) - Taku fe vidi, de leta shaloftni Pild ali tu terplenje Chriftufevu dolgu ne terpi (TPo 1595: II,3). Različne povezave posredno kažejo na večpomenskost pojasnjevanega prevzetega samostalnika. Lahko pa gre tudi za stilno učinkovito nizanje. Npr.: blutig Bild (LH 1566: II,IIIa) - kervavi Pild, ali podoba (TPo 1595: II,2); blutig Bild (LH 1566: II,IIIa) - kervau Pild ali obras (TPo 1595: II,2).

(2) Redkejši so primeri, ko je Trubar za pojasnilo v Lutrovi postili uporabljenega poimenovanja navedel kar tri ekvivalente različnega izvora in neredko pomenskodopolnilnega značaja. Npr.: 1. vnd fich darumb ein rumor in der welt erhebt (LH 1566: I,XXVIII) - de fe fatiga volo Ardrie, kreganje inu fouraftvu, na tem fvetu vfdigneo (TPo 1595: I,46); 2. auch weñ es vbel gehet / in allerley vnglück vnd anfechtung (LH 1566: I,XXVIIIb) - kadar onu hudu gre, vfakateri nefrezhi, reui, nadlugi inu iskufhnjavi (TPo 1595: I,46).

(3) Dvojice, ki jih sestavljata poimenovanji tujega in domačega izvora, številčno prevladujejo. Struktura prevajanega in hkrati pojasnjevanega poimenovanja praviloma narekuje tudi izbor ustrezne tvorjenke ali besedne zveze, kar npr. ponazarja tale zgled: Alfo ein Rottengeyfter gehet daher im rhum (LH 1566: III,XXVIIb) - En taku Rotirarfki duh ali falfh Vuzhenik tudi Semkaj pranga vtej hvali (TPo 1595: III,132).

${ }^{12}$ Zgledi kažejo, da je zaporedje izbranih ustreznic spremenljivo. Npr.: Sonder auff jhre weißheyt / gewalt / vnd reychthumb bochen wöllen (LH 1566: III,LXXX) - temuzh hote le na fvojo Modruft, oblaft, inu Blagu truzati inu fhugati (TPo 1595: III,136).

${ }^{13} \mathrm{~V}$ TPo 1595 se sicer izmenjujejo pogosto rabljene sopomenke prost $(168 \times)$, ledig $(66 \times)$, fraj (47×) in sloboden, ki se pojavlja le dvakrat (enkrat v povezavi s fraj: vnnd wölle frey fein (LH 1566: II,CLXIXb) - de bi hotel fray ali sloboden biti (TPo 1595: II,286)). Večinoma nastopajo v parih. Ledig se npr. v sopomenskem paru pojavlja 51× (ledig inu/ali prost ali prost inu/ali ledig, dvakrat pa tudi v povezavi s fraj). Par ledig inu fraj je npr. Trubar posnel po Lutrovi prevodni predlogi že v novozaveznem prevodu: das sie frey vnd ledig sein sollen (LB 1545: 2060) - de te fatrene ispuftimi frai inu ledig (TT 1581-82: 238). O tekmovalni zaostrenosti med ledig, prost in fraj v Trubarjevih novozaveznih prevodih prim. Merše 1990: 167. 
(3a) Z dvojno formulo tega tipa je lahko opravljena tudi opaznejša besednovrstna oddaljitev od prevodne predloge. Npr.: Gottes fon ift menfch worden [...] er ift vns noch neher gefreundet / fintemal er auß dem fleifch vnd blut der Iungfraw Maria geborn ift (LH 1566: I,XIXb) - je Boshy Syn zhlovik poftal [...] on je nam fhe blifhe vrudi ali vfhlahti, Potehmal je on is tiga Mejsa inu Kry, te Divize Marie, rojen (TPo 1595: I,31).

1.1.2 Pogosti so tudi sopomenski pari, sestavljeni iz domačih poimenovanj. Tudi ti so besednovrstno različni: samostalniški, glagolski, sestavljeni iz prilastkovnih zvez itd. Npr.: 1. Alfo wieget man dif Kindlein ein (LH 1566: I,XVIIIb) - Taku fe letu Diteze Jyble inu vsopy (TPo 1595: I,30); 2. Denn dife wort folten himel vnd erden zerfchmelzen (LH 1566: I,XXIIb) - Sakaj lete befsede bi imejle Nebu inu Semlo respuftiti inu reshgati (TPo 1595: I,37); 3. fo mag fie fich mit jrem mentelein [...] decken (LH 1566: I,XIX) - taku fe ona more s'vojem plazhizhem [prav: plafzhizhem] [...] pokriti ali odejti (TPo 1595: I,30); 4. nicht mehr blutig noch ftrimlich / fonder fchön / lieblich vnd herrlich ift (LH 1566: II,Vb) - kateri nej vezh kervau, ni progaft, ni ranen, temuzh leip, lubesniu inu zhaftit (TPo 1595: II,6); 5. wurde fehr geplaget vnnd gedruckt vom Tyrannen Pharao (LH 1566: II,CLXXXIIII) - je bil filnu inu slu martran inu tlazhen od tiga Tyranna Faraona (TPo 1595: II,311). Trubarjeve glagolske dvojice so za povrh večkrat urejene vidskoparno: v 1. zgledu npr. prvi člen para označuje trajajoče dejanje, drugi pa ciljno dovršitev dejanja. Parno lahko nastopajo tudi poimenovanja, ki se bolj ali manj pomenskosestavinsko razlikujejo (2. in 3. zgled). V predzadnjem zgledu, kjer so v tričlenski niz povezani prilastki, je Trubar z razširitvijo prvega dela s tretjim členom ustvaril protipomensko uravnoteženost. V zadnjem zgledu je glagolska dvojna formula iz predloge dopolnjena še s prislovno.

(1) Na razširitev je domnevno lahko vplivala drugačna praktična izkušnja, pridobljena v domačem okolju, npr. glede načina (kaznovalnega) udarjanja po glavi: vnd die leute geftanden / vñ nit haben nider gekniet / hab er einen auffs maul gefchlagen / vnd jn gefcholten (LH 1566: I,XIXb) - inu ty ludje fo ftali, inu nejfo doli pokleknili, je on [Hudizh] eniga po vftih ali sa uhu, fhinil, inu ga je krejgal (TPo 1595: I,31). V prikaz čustveno stopnjevane situacije se vklaplja tudi izbor ekspresivnega glagola šiniti, ki je bil pred letom 1595 uporabljen le v pesmarici iz leta 1563, torej besedilnozvrstno omejeno in v prav tako nenevtralnem okolju: $\mathrm{Ner}$ pred pred Caiphafa pelan, Od niega fa fuoi vuk vprashan, Tudi ker bi Iogri bili, En hlapez ga vfobe shini (*P 1563: 106).

(2) Razširitev v domači sopomenski par, sestavljen iz znanih poimenovanj, običajno nima predvsem pojasnjevalne vloge, ima pa stilno, saj zaporedna navedba sopomenk oblikuje uravnotežene dvojne formule. Npr. 1. fie keinen raum hetten in der herberge (LH 1566: I,XVIIIb) - ona nejfta proftora ali mejfta imela vErpergah (TPo 1595: I,30); 2. in folcher fchwachheyt ift ein vnüberwindlicher gewalt verborgen (LH 1566: II,IIIIb) - taku je vfaj vener vtakovi slabufti ena nepremogozha oblaft ali muzh skrivena (TPo 1595: II,5); 3. So hat doch Gott vns mehr vnd höher geehret (LH 1566: I,XIX) - taku je vfaj Bug nas vezh inu vifsokeifhi pofhtoval ali zhaftil (TPo 1595: I,31). 
(3) Tudi izrazito kontekstualno vezane rabe je Trubar predstavno približeval z dodatkom ene ali več sopomenk, običajno glagolskih. Npr.: Alfo zur kunft: (LH 1566: I,XXVIIb) - Taku h'kun/hti more inu ima eden rezhi (TPo 1595: I,44). Navedeni zgled kaže na parno pojavljanje naklonskih glagolov. Glagol moči je tudi sicer pogosta sestavina različnih prirednih povezav, zlasti z drugimi naklonskimi glagoli. Npr.: 1. er kan es auch wider nemen (LH 1566: III,LXXVIIb) - On je tudi sna inu more supet vseti (TPo 1595: 132); 2. der darff fich wol rhümen (LH 1566: III, LXXXVb) - ta fe fmej inu more dobru h'valiti (TPo 1595: III,146). Med posebej ustaljene povezave spada tudi par znati inu moči

Podobno ustaljene in trdne so tudi zveze sopomenskih rekanjskih glagolov. Npr.: 1. Denn was fie bißher gefagt / das bleybt in der welt (LH 1566: III,LXXXb) - Sakaj kar je ona dofehmal govorila inu pravila, tu oftane na tem Svejtu (TPo 1595: III,137); 2. das er auch möchte rhümen (LH 1566: I,XX) - de bi fe on tudi mogel hvaliti, inu rezhi (TPo 1595: I,33); 3. Da tröftet vnnd vnterrichtet der Engel die Weyblein / Chriftus fey nit mehr da [...] vnd fie follen jn in Galilea Sehen / vnd befehlen / das fie eilends hingehen / vnd feinen Iüngern folches verkündigen follen (LH 1566: II,IIb) - Natu ta Angel trofhta inu podvuzhy te Shenize rekozh, Chriftus nei vezh tukaj [...] vGalilei ga imaio viditi, inu de bi Imeili jiti inu takovu Iogrom ofnaniti (TPo 1595: II,2). Prvi in drugi zgled kažeta, da je k izoblikovanosti glagolske dvojne formule neredko pripomogel Trubarjev pripis glagola rekanja, ki jasneje napoveduje premi govor. ${ }^{14}$ Zadnji zgled, kjer je uporabljen rekanjski deležnik, hkrati kaže, da je v Lutrovi prevodni predlogi na premi govor pokazano tudi sobesedilno. Preverjanje širšega sobesedila pa razkriva, da pripis glagola člensko uravnoveša kasnejši izpust ekvivalenta za glagol befehlen, ki sicer modalno barva poročano dogajanje.

(4) Obstajajo tudi primeri hkratne širitve različnih stavčnih členov iste povedi, npr. povedka in prislovnega določila načina: das der Teuffel fich folt feltzam verdrehen (LH 1566: I,XXVI) - de bi fe ta Hudizh vmel taku Jmeifhnu inu zudnu [prav: zhudnu] sviti inu potozhiti (TPo 1595: I,42). Pojasnjevalnega in hkrati dopolnilnega značaja je tudi naslednja razširjena zveza v Trubarjevem prevodu: Bethlehem [...] die nicht fo vil ehr jhrem Heyland beweyfet / das fie jhm jrgend ein multern zur wiege / oder ein banck pfül für ein küffe leyhet (LH 1566: I,XVIIIb) - Betlehem [...] nej tulikajn zafty [prav: zhafty] fvojmu Isvelizharju iskasalu, de njemu kej enih nizhiz k'sybeli, ali kej en v/sinat polfhter, ali en flamni fhakel keni vaiku/hnizi ne po/sodi (TPo 1595: I,30). Zgled kaže, da je nemška zveza ein banck pfül potrebovala prilagoditveno in hkrati predstavno približanost.

(5) Tudi kompleksnejše besedilne preureditve in hkrati oddaljitve od prevodne predloge pogosto zadevajo uporabo dvojnih formul: npr. vpeljavo nove (prislovne) in opustitev v predlogi zapisane (glagolske). Npr.: Das heift ja tieff fich demütigen / vnd herunter lafsen (LH 1566: I,XIXb) - Tu fe pravi ja globoku inu Vifsoku ponifhati (TPo 1595: I,32).

${ }^{14}$ Podobne primere, prav tako razlikovalne glede na nemško prevodno predlogo, je mogoče zaslediti v Dalmatinovi Bibliji. Prim. Merše 2009: 47, 80. 
1.2 Drobne razlike med prevodoma ustvarjajo tudi številni drugi Trubarjevi dodatki (npr. razširitev prilastkovne zveze), ki so prav tako posledica prizadevanja, da bi bila vsebina razumljiva in da bi povedano doseglo želeni učinek. Mestoma je z njimi opazno stopnjevana ekspresivnost. Npr.: denn dife verfluchte art henget vns allen natürlich an (LH 1566: I,XXVII) - Sakaj leta prekleta huda shega po naturi na nas vifsi (TPo 1595: I,44).

Podaljšanje naštevalnih nizov je večkrat povezano s svobodnejšo izbiro posameznih ekvivalentov. V sledečem primeru se je Trubar odločil celo za ekspresivnejše nadomestne izraze: leute [...] die am Geyfte arm find / das ift / die engftige / bekümmerte hertzen haben (LH 1566: II,CLXXXIIb) - ludje, kateri fo na Duhu vbosi, tuje, kateri ftyfnena, kumrana inu shaloftna ferza imajo (TPo 1595: II,309).

Vzorčne zglede je mogoče poiskati tudi za pomnoženost modalnih elementov. Npr.: vnd wolte fie leyden (LH 1566: III,LXXX) - inu bi nje hotel rad terpejti inu viditi (TPo 1595: III,136). ${ }^{15}$ Na rahljanje modalne določenosti kažejo primeri parnega nastopanja glagolov, ki izražajo različen odnos do dejanja: denn Gott kan jn nit leyden (LH 1566: III,LXXXI) - Sakaj Bug nje ne hozhe inu ne more terpejti (TPo 1595: III,137). Opazni so tudi primeri poudarjanja osebnega odnosa do sporočane vsebine: npr. Vnnd zwar thuts die welt redlich (LH 1566: III,LXXXIIIIb) - je rejs, ta Svejt je tudi gvifhnu ftury (TPo 1595: III,144).

1.2.1 Med značilne Trubarjeve dodatke se pogosto uvrščajo prilastki in členki:

\begin{tabular}{|l|l|l|l|l|l|l|l|l|l|}
\hline $\begin{array}{l}\text { LH 1566 } \\
\text { (I,XXII) }\end{array}$ & Solchs & mag & vol & ein & & gedancken & oder & war & fein \\
\hline $\begin{array}{l}\text { TPo 1595 } \\
(\mathrm{I}, 35)\end{array}$ & Takovu & more & dobru & ena & negvifhna & mifsal, & ali & rejs & biti \\
\hline
\end{tabular}

1.2.2 Trubar je po lastni presoji posamezne elemente bodisi dodajal ali izpuščal. Več primerov kaže, da je izpuščal ekspresivnejše vsebinske elemente, dodajal pa je npr. okoliščinska določila, ponavljal že omenjene osebke, vključeval predmete, zamenjeval zaimke s konkretnejšimi samostalniki - vse z namenom, da bi ohranjal v zavesti osnovna dejstva in vzdrževal predstavo. Npr.: 1. Da nun diefelben zwen Iünger eylend wider nach Ierufalem rennen / vnd den andern verkündigen wöllen / was jhnen begegnet fey [...] vnd fie folches fich verwundern / vnd doch noch nit alle glauben können (TH 1566: II,IIIa) - Kadar vfhe taifta dva mlaifha fta supet vIerufalem tekla, inu tem drugim osnanila, tu, kar fe je nyma vEmaufi pergudilu [...] so fe ty Iogri takoviga sazhudjli, ali vfai nekateri vmei nymi, tem beffedam, nefo verovali (TPo 1595: II,2); 2. Ietzt befchleuft fie / die liebe Iungfraw / vnd finget zu letzt von der grö/ten gnad (LH 1566: III,LXXXb) - Sdaj dokonja nje pei/sen ta luba Diviza, inu poje hpuflednimu od te velike gnade (TPo 1595: III,137); 3. Denn die fumma dauon / ift dife (LH 1566: II,CLXXXIb) - Sakaj ta fumma tiga Evangelia je leta (TPo 1595: II,307). Prvi zgled hkrati kaže tudi na doseganje iste informativnosti z različnimi sredstvi: nit alle - ne-

${ }^{15} \mathrm{Na}$ kopičenje naklonskih izrazov ob pogojniku, kar se razkriva kot značilnost slovenskega knjižnega jezika 16. stoletja, je bilo že opozorjeno (Merše 2009: 101). 
kateri vmei nymi. Luter je številčno omejitev nosilcev stanja dosegel z zožitvijo celote, Trubar nasprotno z izločitvijo manjše skupine.

Zaslediti pa je mogoče tudi manj jasne nadomestitve. V nemški različici odlomka iz Lukovega evangelija je npr. omenjen Jezus, ki ga je Trubar v slovenskem prevodu nadomestil z manj določnim on. Na zamenjavo je verjetno vplivalo prepričanje, da je odlomek iz evangelija, ki ga ob vključitvi v postilo ni dodatno prirejal, dovolj znan in da bi med bralci postile težko prišlo do neprepoznavanja oz. napačne identifikacije udeležencev dogajanja: Vnnd Iefus Jprach zu jn (LH 1566: III,LXXXII) - On pak je rekal k'nym (TPo 1595: III,139).

1.2.3 Boljšemu razumevanju vsebine so bili namenjeni tudi daljši vrivki. Npr.: 1. Alfo würd folch bilde / wo es recht im hertzen were / inn eim augenblick / alle grewliche Exempel des zorns Gottes verfchmeltzen (TH 1566: I,XXIIb) - Ia leta pild de je Bofhy Syn zhlovik poftal, kadar bi on prav verzi bil, bi on uvenim hipu, vfe grofovite Exemple tiga ferda Boshyga reftupil (TPo 1595: I,36); 2. So ein reiche materi ifts (TH 1566: II,IIb) - taku ena bogata materia inu Vuk je ta articul od tiga gori vftaienja nafhiga GOSPVDA Iefufa Chriftufa (TPo 1595: II,2); 3. Vberfihet alfo das fpil / vnd vergreifft fich an der perfon (LH 1566: II,IIII) - Satiga volo Pregleda inu Jgubi ta Smert to ygro, inu fe na tej Perfoni Chriftufeue [...] fama viame, kir ie na toifto perfono krivu fegla (TPo 1595: II,4); 4. lauffen fie mit hauffen vom Grab / einer da / der ander dort hinauß (TH 1566: II,IIb) - fo ony s'haufnom od Groba tekli, edan Semkai ta drugi tjakaj, kamer je veidil inu mogel (TPo 1595: II,2). Predzadnji zgled kaže na Trubarjevo premišljeno, večstopenjsko razširitev prevoda. Dostavek v zadnjem zgledu je domnevno rezultat uveljavljene rabe. Trubar je s tovrstnimi razširitvami odstranjeval možnosti za napačno razumevanje besedila, ki bi ga lahko povzročilo morebitno popuščanje pozornosti.

Neredke so pojasnjevalne razširitve, izpeljane s pomočjo navezave tipa $t u$ je: ${ }^{16}$ können derhalb nimmermehr auff einen grünen zweig zu fitzen kommen (LH 1566: II,CLXXXII) - ne mogo sa tiga volo nikuli vezh na eno seleno vejezo priti, tu je, ony nemajo vshytka, shegna, frezhe ni fdravia imejti (TPo 1595: II,308).

$\mathrm{Z}$ enostransko ponovitvijo dela zložene povedi (kot prilastkovega odvisnika in kot dela vezalnega priredja) je ustvarjen stilno učinkoviti refren: Chriftus hat außgetilget die hand fchrifft / welche durch das gefetz entftunde / vnd wider vns war / die Selbe hat er weg gethan (TH 1566: II,IIII) - Chriftus je isbrifsal, nashe roke pifmu, kateru je fupar nas bilu, kateru je vftalu Jkusi poftave, inu je fupar nas bilu, inu je tuiftu is frejde prozh djal (TPo 1595: II,4).

1.2.4 Čeprav je mogoče opaziti veliko mest, kjer je Trubar z izpustom ekspresivnejših izrazov (npr. pridevnikov, prislovov) ali z njihovo nadomestitvijo s pomensko blažjim izrazom čustveno nevtraliziral prevod, so tudi mesta, kjer je nasprotno pripoved intenziviral z dodatkom čustveno »ojačevalnega« pridevnika. Npr.: 1. fie [...] ein fondern

${ }^{16}$ Na dejstvo, da je zveza značilna sestavina Trubarjeve gradnje stavkov in odstavkov ter njegove retorike, je opozorila B. Pogorelec (1972: 311-312). Na pogosto Trubarjevo rabo retorične oblike (de)finitio, izpeljane s pomočjo uvajalne zveze tu je, opozarja tudi Ahačič (2007: 305). 
ftoltz vnd mut hat (LH 1566: III,LXXVII) - ona [...] eno fu/sebno dobro volo inu vesselu ferze ima (TPo 1595: III,131); 2. dife verfluchte art (LH 1566: I,XXVII) - leta prekleta huda shega (TPo 1595: I,44). Navajanje več približnih ustreznic je lahko tudi rezultat iskanja primernega ekvivalenta. Npr.: Ift es aber nit ein verdrießlicher handel (LH 1566: I,XX) - Nej li onu pak ena garda framotna reizh (TPo 1595: I,32).

(1) Med dodanimi prislovnimi določili, značilnimi za Trubarja, izstopa tudi zveza od smerti gori vstati, ki jo je v prehodni različici gori obuditi (koga) od smrti uporabljal že v najzgodnejših biblijskih prevodih (prim. Merše 1990: 175). Dodatek od smrti je hkrati izključeval sleherno dvoumnost glede Kristusovega dejanja in njegove enkratnosti. Npr.: Chriftus fey nit mehr da / er fey aufferftanden (LH 1566: II,IIb) - Chriftus nei vezh tukaj, temuzh je od Smerti gori vftal (TPo 1595: II,2).

1.2.5 Med značilne Trubarjeve razširitve spada tudi dodani prevod latinskega citata, ki ga Luter ni vključil: Vnd dennoch ift auch in folchem Kirchenregiment ein ordnung / vnd vnterfcheid / der da heyft: Differentia donorum, fed non poteftatis (LH 1566: III,LXXXIIIb) - Inu je vener tudi vtakovim Cerkounim Regimentu ena ordninga inu reslotik, kateri bode imenovan: Differentia donorum, fed non poteftatis, tu je teh darou en reslotik, nikar pak te oblafti (TPo 1595: III,143). Drugovrstna prevodna oddaljitev je nadomestitev latinskega citata s prevodom, razumljivim domačim bralcem: Widerumb helt fie es für ein felig ding / wo folche ang/t vnd anfechtung nit ift / da mens foluta curis ift (LH 1566: II,CLXXXII) - spetnasaj je fvejt dershy sa eno frezhno rejzh, kir takove britkufti, shalofti, reve ali iskufhnjave nej, inu je tu ferze ali mi/sal pres Jkarbi (TPo 1595: II,308).

2 Primeri opuščanja dvojnih in trojnih formul oz. daljših, veččlenskih nizov ter nadomeščanja sopomenskih ali blizupomenskih parov in nizov bodisi z enim samim poimenovanjem (najpogosteje glagolskim, lahko tudi samostalniškim, pridevniškim, opisnim itd.) ali s člensko okrajšanim, so veliko redkejši, vendar kot vrsta prevodne korekture vseeno opazni. Npr.: 1. Soches würde vns bewegen vnd treiben / das wir von hertzen auch würden andern leuten gern helffen vnd dienen (LH 1566: I,XXb) Takovu bi nas gnalu, de bi my is ferza tudi drugim ludem radi pomagali, inu flushili (TPo 1595: I,33); 2. Das laffe ein fchröcklich / jemmerlich vnd grewlich teuffels reich fein (LH 1566: I,XXI) - Tu ti pufti enu ftrafhnu, inu grosovitu Hudizhevu krajleftvu biti (TPo 1595: I,34); 3. Diß ift der rechte / höch/te / vnnd befte troft / da man Gottes gnade vnnd barmhertzigkeit gantz eigentlich vnd geviß prüfen kan (LH 1566: I,XXIIIIb) - Tu je ta pravi, nar vifsokeifhi, inu nar bul/hi trofht, kadar fe more Boshja Gnada imeiti (TPo 1595: I,39); 4. difliedlein oder gefang verkeren (LH 1566: I,XXVI) - leto Peifam preverniti (TPo 1595: I,42); 5. die lehr des heutigen Euangelij fein gantz fasfen (LH 1566: III,LXXVII) - ta Vuk tiga danafhniga Evangelia kratku sapopafti (TPo 1595: III,131); 6. er könne die befte vnnd höchfte kunft (LH 1566: III,LXXXVb) - on sna to nar bulfho kunfht (TPo 1595: III,146); 7. Ehr vnd lob fey [...] meinem gewalt / gunft / kunft / rc. (LH 1566: I,XXVIIb) - Zhaft inu hvala bodi letukaj [...] mojej Oblafti, kunfhti, \&c. (TPo 1595: I,45). V 2. zgledu je po presoji prevajalca izpadla informativno manj obremenjena in pogrešljiva enota. $\mathrm{V}$ 
3. zgledu je mogoče opaziti znatno skrajšavo zadnjih dveh, besednovrstno različnih dvočlenskih stavčnih delov: predmeta, ki je sestavni del zgradbe z nedoločnim zaimkom man (slednji nastopa $v$ vlogi splošnega vršilca dejanja), ${ }^{17}$ ter prislovnega določila načina iz istega stavka, saj je $\mathrm{v}$ trpni zgradbi, uporabljeni v Trubarjevem prevodu, predmet iz predloge pretvorjen $\mathrm{v}$ enočlenski osebek, prislovnega določila načina pa ni. Četrti zgled kaže, da je na izpust enega od členov para lahko vplival premislek o njuni pomenski neizenačenosti, saj par sestavljata manjšalnica in nemanjšalnica. $\mathrm{V}$ 5. zgledu je opravljen rahel odmik od predloge. Navzven ga napoveduje nadomestitev dveh prislovov z enim samim, ki ne more pomensko ustrezno nadomeščati obeh, saj eden dejanje označuje kakovostno, drugi pa količinsko. Predzadnji zgled kaže na okrajšanje zveze, ki bi v celoti prevzeta ne zvenela enako uglajeno kot pri Lutru. V zadnjem zgledu se Lutrov tričlenski niz izteka z glasovno delno prekrivnima členoma, česar Trubar ni mogel ponoviti niti z izpustom srednjega člena niti z drugačnimi sredstvi. Vzrok za skrajšavo je lahko bila tudi težje prevedljiva sopomenka. Zaradi obilice Trubarjevih lastnih dvojnih formul pa tovrstne opustitve ne izstopajo.

Nekateri enočlensko nadomeščeni sopomenski pari iz predloge pa so kot vzorčni model aktivno upoštevani drugje. Npr.: nutz vnd brauch kot vzorec za nuc inu prid (Ich rede aber noch nit von dem nutz vnd brauch (LH 1566: I,XXII) - Ieft pak fhe negovorim od tiga prida (TPo 1595: I,35); wer Gottes wort fleiffig höret / der hat zwen groffe vortheyl (LH 1566: II,XCb) - kateri Boshjo befsedo poflufha, ta ima dva velika nuza ali prida (TPo 1595: II,151)). ${ }^{18}$

2.1 Nekaj elementov z izrazitejšo čustveno konotacijo iz Lutrove predloge je Trubar opustil. Na tovrstno prakso poleg že navedenih primerov ${ }^{19}$ kažejo tudi naslednji: $1 . N u$ aber / fingen lieben Engel (LH 1566: I,XXVII) - Nu pak, pojo ty Angeli (TPo 1595: I,44); 2. Was ift die welt anders denn die leydige Helle (LH 1566: I,XXVIIb) - Kaj je ta sveit drusiga, kakor ta Pakal (TPo 1595: I,45). Isti pridevniki ob istih odnosnicah so bili opuščeni večkrat, ne pa vedno. Trubar je opuščal tudi prislove: 1. das wir auff erden follen fein brüderlich vnter einander leben (LH 1566: I,XXVIII) - de na Semli bratoufku mej fabo shivejmo (TPo 1595: I,46); 2. Da [...] vnterrichtet der Engel die Weiblein / Chriftus fey nit mehr da [...] Jie Jollen jn in Galilea Jehen / vnd befehlen / das fie eilends hingehen (LH 1566: II,IIb) - ta Angel [...] podvuzhy te Shenize rekozh, Chriftus nei vezh tukaj [...] vGalilei ga imaio viditi / inu de bi Imeili jiti (TPo 1595: II,2).

2.1.1 Nasprotno pa so bile zmerjavke pogosto zvesto prevedene in hkrati posnete po predlogi. Npr.: 1. Pfuj dich an (LH 1566: I,XIXa) - Pfuj te bodi (TPo 1595: I,31); 2. Du grober fchelm (LH 1566: I,XIXb) - Ti grobi fhelm (TPo 1595: I,31). Prvi primer kaže, da je bila ohranjena celo vezava.

${ }^{17}$ Strukture z nedoločnim zaimkom man v nemščini lahko nastopajo v vlogi paralel trpnih zgradb, saj so vanje pod določenimi pogoji tudi pretvorljive. Prim. Helbig - Buscha 1996: 185-186; Muster Čenčur 1998: 166-167.

${ }^{18}$ Samostalnika $n u c$ in prid se v TPo $159545 \times$ pojavljata v paru. Običajna je razvrstitev nuc inu/ali prid, obrnjena pa je redkejša.

${ }^{19}$ Prim. razdelek 1.2.2 in drugod. 
3 Razlike, ki se primerjalno kažejo med nemško prevodno predlogo in Trubarjevim prevodom, je mogoče opazovati tudi po jezikovnih ravninah.

3.1 Pogoste in opazne so razlike glede izbire besedja, zlasti tiste, ki so določene $\mathrm{z}$ besedotvorno različnostjo jezikov. ${ }^{20}$

3.1.1 Prevodne ustreznice za značilne nemške samostalniške zloženke predstavlja nekaj znanih tipov besednozveznih nadomestil. ${ }^{21}$ Npr.: in den küftal (LH 1566: $\mathrm{I}, \mathrm{XVIIIb}) \rightarrow$ vto kravjo Jhtalo (TPo 1595: I,30); betgewand (LH 1566: I,XX) $\rightarrow$ poftelniga gvanta (TPo 1595: I,32); dife Engelpredig (LH 1566: I,XXVb) $\rightarrow$ leta Angelfka Pridiga (TPo 1595: I,41). V navedenih zgledih nemške zloženke nadomeščajo zveze prilastka in odnosnice. Prilastek ustreza prvemu delu zloženke. Drugačno rešitev izkazujeta naslednji prevodni mesti: Mit difer verfluchten ehrfucht (LH 1566: I,XXVII) $\rightarrow$ Sleto prekleto bolesanjo po zhafti (TPo 1595: I,41); nothelffer (LH 1566: III,LXXX) $\rightarrow$ pomozhnik is nadlug (TPo 1595: III,137). V obeh primerih prvi (samostalniški) člen nemške zloženke v Trubarjevem prevodu nadomešča zapostavljena predložna zveza.

(1) Na prevajalske zadrege svojsko kažejo samostalniški kalki tipa rokepifmu za handfchrift, saj se je Trubar zadovoljil s sestavinskim prevajanjem in ni skušal iskati drugega sopomenskega nadomestila. Na rahlo oddaljevanje od predloge občasno kaže ločen zapis sestavin, ki omogoča tudi njihovo ločeno sobesedilno vključevanje. Npr.: Dife handfchrifft [...] entftehet durchs gefetz (LH 1566: II,IIII) - Letu rokepifmu [...] vftane Jkusi to Poftavo (TPo 1595: II,5); die fünde vnd die handfchrifft / die vns vberweyfet (LH 1595: II,IIII) - ta Greih inu te Roke pifmu, kateru nas previ/ha (TPo 1595: II,5).

(2) O prevodnih razhajanjih, ki jih predstavlja izbira manjšalnice namesto izhodiščnega samostalnika v prevodni predlogi ali obratno, prim. Merše 2010: zlasti 59-60. Npr.: 1. Diß ftücklein follen wir auffs erfte von difer gefchicht mercken (LH 1566: I,XX) - Leta shtuk imamo my h'pervimu od letiga djainja merkati (TPo 1595: I,32); 2. auff einen grünen zweig (LH 1566: II,CLXXXII) - na eno seleno vejezo (TPo 1595: II,308). Tudi nadomeščanje manjšalnic z nemanjšalnimi tvorjenkami je mogoče uvrščati v sklop zmanjševanja ekspresivnih elementov.

${ }^{20} \mathrm{Na}$ skladnosti in razlike $\mathrm{v}$ besedotvorno-pomenskem sestavu slovenskega, latinskega in nemškega jezika, ki jih je odkrila primerjalno zasnovana analiza besedotvornih vzorcev $\mathrm{v}$ prevodih slovenskih protestantskih piscev 16. stoletja in v njihovih prevodnih zgledih, na več mestih opozarja M. Orožen (1996: 151-152 (o Trubarjevem načinu prevajanja) in 246-247 (o Dalmatinovem načinu)).

${ }^{21} \mathrm{O}$ tipih slovenskih ustreznic (enobesednih in besednozveznih) za nemške samostalniške zloženke v Megiserjevem slovarju (npr. Rebblat - tertin lift, vinske terte lyft, lyft od terte) iz leta 1744 prim. Orožen 2003: 203-205. A. Vidovič Muha (1997: 39-54) je iste tipe ugotavljala pri analizi slovenskih ustreznic za nemške zloženke v Gutsmanovem slovarju (1789) in jih razvrščala glede stopnje vraščenosti v slovenski jezikovni sistem (npr. Brautbett-nevestna postel, Windschade - škoda od vetra). 
3.1.2 Tudi nemške pridevniške zloženke so neredko nadomeščene z ustrezno številnim nizom ustreznic sestavin prevajane tvorjenke: Alfo ift es hie mit difer heyligen / freudenreychen geburt (LH 1566: I,XXb) - Taku je onu letukaj sletim fvetim, veseljm, bogatim rojftvum (TPo 1595: I,33).

3.1.3 Razlike se neizogibno kažejo tudi pri prevajanju nemških glagolskih zloženk, saj istovrstnih slovenščina nima. Trubar je npr. kot nadomestilo za nemški ločljivo sestavljeni glagol liebgewinnen uporabil zvezo za ljubo imeti: Denn da were nicht wunder / wenn wir gleich fonft nichts dauon hetten / das wir menfchen vnter einander vns fo lieb folten gewinnen / das eins das ander für liebe / wie man fagt / freffen folt (LH 1595: I,XXII) - Sakaj tukaj bi ne bilu zhudu, kadar bi my lih ficer nifhter od tiga nejmejli, de bi fe my zhloveki mej fabo taku sa lubu imejli imejti, de bi eden tiga drusiga od lubefni, kakor fe pravi, imel fnejfti (TPo 1595: I,35). Navedeni zgled kaže tudi na Trubarjevo hoteno izbiro manj ekspresivnega glagola za oznako človeškega ravnanja: fressen $\rightarrow$ snesti.

(1) Spremenjeno izbiro si je pogosto mogoče razlagati kot posledico različnega besednega inventarja obeh jezikov, širše pogojenega z njuno različnostjo. Npr.: das die krigßknecht $[\ldots]$ folcher aufferftehung nit jnnen werden (LH 1566: II,IIb) - de ty sholnerji [...] ta koviga Gorivftajenia ne fo svejdili (TPo 1595: II,2).

3.1.4 Naštete nadomestitve nemških samostalniških, pridevniških in glagolskih zloženk z besednozveznimi nadomestili so jezikovnosistemska korektura, ki jo terja drugačen ustroj slovenskega jezika.

3.1.5 Trubarjev prevod je tudi v poznih življenjskih letih, daleč od domovine in ob oslabeli izkušnji žive vsakdanje (slovenske) govorice - zaradi dolgoletne odsotnosti - napredoval in uspeval tudi po zaslugi kalkiranega prevajanja. Z njim je Trubar premagoval večje ubeseditvene zadrege. Med dodobra uveljavljene kalke spada prevajanje zveze vorhanden sein s sestavinskim prevodom biti pred rokami (prim. Novak 2004: 186).

(1) $\mathrm{Za}$ številne kalkirane glagole s prislovno sestavino $\mathrm{v}$ vlogi predpone velja, da Lutrova predloga izbire ni neposredno spodbujala. Trubarjeva izbira dokazuje njihovo vraščenost v rabo. ${ }^{22}$ Npr.: 1. Da es nu am Sontag [...] Jehr frü ift / das die morgenröte jetzt daher wil ftreichen (LH 1566: II,IIb) - Kadar je onu v/he vNedello [...] cilu fgudo billu, inu ta sarja fdaj ie Imela gori jit (TPo 1595: II,2); 2. das wir menfchen auch follen fröhlich fein / vnnd folche gnad mit danck annemen (LH 1566: I,XXIII) - de bi my zhloveki tudi imejli vefseli biti, inu takovo Gnado s'hvalo gori vseti (TPo 1595: I,37). V isto skupino je mogoče uvrščati tudi glagol antikati, ki na ustreznem mestu Lutrove postile nima tvorbeno enakovredne oz. izbirno sugestivne ustreznice: Der Hiftori halb hat es fo zugangen (LH 1566: II,II) - Kar pak to Hiftorio antizhe fe je taku godilu (TPo 1595: II,1).

(2) Na uresničenost celotne palete možnosti, ki sega od skladne izbire glagolskih zloženk do samo enostranske - slednja spet dokazuje bodisi uveljavljenost kalkov

22 Prim. Merše 2009: 129-141. 
ali tvorbeno premišljene in prav tako uveljavljene odmike od nje -, kažejo tudi primeri nadomestne izbire predponskih glagolov. Tudi te je Trubar pogosto vpletal v glagolske dvojne formule kot sopomenke oz. nadomestila kalkov: Npr.: 1. da der Engel vom himel herab kommen / vnnd den ftein vom Grabe hinweg gethan habe (LH 1566: II,IIb) - kadar je ta Angel od Neba prifhal, inu ta kamen od Groba odvalil (TPo 1595: II,2); 2. Das heyft hinweg geworffen allerley lehr vnd Religion (LH 1566: I,XXVb) - Tu fe pravi vfe Jhlaht Vukuve inu Vere fapuftitt inu sauvrezhi (TPo 1595: I,41).

Nekatere nemške glagolske tvorjenke je Trubar predponsko in priponsko podomačil. Med besedne »prispevke« njegovega prevoda Hišne postile spadata tudi glagol pognadati in deležnik pognadan. Npr.: Gott hat fie begnadet (LH 1566: III,LXXIX) - Bug je njo pognadal (TPo 1595: III,134).

(3) Za izražanje sočasnih dejanj je Trubar namesto nedoločnika v predlogi pogosto izbral deležnik: DER Herr Ihefus fahe einen menfchen am Zoll fitzen (LH 1566: III,LXXXV) - GOSPVD Iefus je vidil eniga zhlovéka na zolu fidezhiga (TPo1595: III, 145).

3.1.6 V niz kalkirano prevedenih struktur spadajo tudi prislovne, med katerimi po pogostosti izstopa naslednja: Widerumb gibt er armen leuten offt groffes glück (LH 1566: III,LXXX) - supet nasaj on da vbosim ludem zheftu veliko frezho (TPo 1595: III, 136).

3.1.7 Svobodnejši prevod je Trubarju omogočala tudi izbira medmetov in členkov. Mestoma se je odločal tudi za drugo, za slovensko rabo bolj značilno navezovalno ali vsebinsko povezovalno sredstvo: Sihe / die zwey Eheleutlin find in einem frembden land (LH 1566: I,XVIII) - Sakaj, leta dva Sakoinika Jta uveni ptuji Desheli (TPo 1595: I,30).

3.1.8 V TPo 1595 je mogoče zaslediti več na novo prevzetih izrazov, ki izkazujejo le najnujnejšo prilagoditev slovenskemu besedotvornemu in oblikoslovnemu sistemu. Npr.: gleichmeffiges recht gehen laffen (LH 1566: III,LXXXIII) - eno glihoma/sno praudo inu pravizo vfem glih foditi (TPo 1595: III,141). ${ }^{23}$

3.2 Oblikoslovne razlike. Nekatere prevodne razlike je mogoče opredeljevati kot oblikoslovne.

3.2.1 Izbira ednine namesto množine je praviloma individualna in ne jezikovno pogojena. Več primerov pa kaže na enostranski izbor skupnega poimenovanja v ednini nasproti množinski rabi. Npr.: 1. Denn alfo theylet Marcus die ftunde vnnd zeyt (LH 1566: II,IIb) - Sakai taku dily S. Marcus te ure inu zhaffe (TPo 1595: II,1); 2. So fihet man an vnferm Adel (LH 1566: II,IIIb) - Taku Je vidi na nafhih Shlahtnikih (TPo 1595: II,3).

${ }^{23} \mathrm{O}$ besednozakladnem prispevku postil, tudi TPo 1595, ocenjevanem v okviru slovenskega knjižnega jezika 16. stoletja, prim. Merše 2007. 
- (1) Nasprotno pa je Lutrova izbira množinske oblike men $\int c h \rightarrow$ men $\int c h e n$ tudi Trubarja usmerjala k izbiri množinske oblike zhloveki in le redko k danes uveljavljeni drugokorenski različici ljudje. ${ }^{24}$ Slednja se običajno pojavlja kot prevodna ustreznica za leute ali kot najpogostejše nadomestilo za nedoločni zaimek man. ${ }^{25}$ Npr.: 1. das wir menfchen auch follen fröhlich fein (LH 1566: I,XXIII) - de bi my zhloveki tudi imejli vefseli biti (TPo 1595: I,37); 2. Darumb folten folche leute haß vnd neyd fallen laffen (LH 1566: I,CXVI) - Satu imajo taki Ludje nid inu fourafhtvu puftiti pafti (TPo 1595: I,196).

3.2.2 Opaženo je že bilo (Merše 2007: 80-81), da je Trubar nadomeščal iz nemščine prevzete, pregibno rabljene pridevnike z nepregibno rabljenimi. Npr.: mit dem groben Klotz (LH 1566: I,XXVII) - stejm grob painom (TPo 1595: I,44); mit der Jubtilen Abgötterey (LH 1566: I,XXVII) - s'tém Jubtil Malikovaujem [prav: Malikovanjem] (TPo 1595: I,44); Das ift die dritte leyfe / das man ein frölichen / freydigen / trotzigen mut habe (LH 1566: I,XXVIIIb) - Tu je ta tretja Verfta ali ftava de ludje eno vefselo, frajdig, truzig mi/sal imajo (TPo 1595: I,46).

3.2.3 Znani in pričakovani so popravki vidskega značaja oz. vidsko premišljena izbira glagolov. Npr.: 1. wie gefagt (LH 1566: I,XX) - koker je proprei prauvlenи (TPo 1595: I,32); 2. auff das wir nit allein am exempel der Iungfrawen Marien zucht / demut vnd glauben lernen / Sondern auch auß jrer predig lernen (LH 1566: III,LXXVII) - de fe my nikar le na tem Exempli te Divize Marie pofhteinja, pohleufzhine inu vere navuzhimo, temuzh fe tudi is nje Pridige vuzhimo (TPo 1595: III,131). Zaslediti pa je mogoče tudi redke vidsko manj premišljene popravke. Npr.: der höre nur bey zeyt auff ein Chrift zu fein (LH 1566: II,CLXXXIII) - ta le per redu nehaj en Karfahenik poftati (TPo 1595: II,310).

(1) Zaznati je mogoče tudi nekaj korektur časovne predstavitve dogajanja. Trubar ponekod ponuja drugačne rešitve, tipične za slovenski in neredko tudi za nekatere druge slovanske jezike. Npr.: Denn alle [...] werden fagen (LH 1566: I,XXVII) - Sakaj vfy ty [...] poreko (TPo 1595: I,44). ${ }^{26}$

(2) Razlika med predlogo in prevodom je večkrat tudi v izbiri tvornika na eni in trpnika na drugi strani. Npr.: Man plagt / dringt vnnd treybt fie fo lange / das jhnen die augen vbergehen (LH 1566: II,CLXXXIII) - ony bodo taku dolgu martrani, drengani inu resshaleni, de fe plazhejo inu jokajo (TPo 1595: II,310).

(3) Jezikovna različnost pogosto odseva tudi v vezavni neenakosti glagolov, čeprav niso redki primeri kalkirane, to je ne vedno med domačimi možnostmi izbrane vezave. V primeru ohranjene, po navadi nemškega jezika posnete vezave pa do

${ }^{24} \mathrm{~V}$ sodobnem slovenskem knjižnem jeziku je uveljavljena številska paradigma človek (dva) človeka - ljudje (prim. SP 2001: 432). Toporišič sklanjatveno kombinacijo človek - ljudje omenja kot zgled za nadomestno osnovo (Toporišič 1992: 115).

${ }^{25}$ Prim. razdelek 3.3.3.

${ }^{26}$ Ustaljeno nemško izražanje futura (sedanjiška oblika glagola werden + nedoločnik) v navedenem primeru nadomešča sedanjiška oblika dovršnega rekanjskega glagola, sestavljenega s predpono po- (o rabi dovršnih glagolov s predono po- za izražanje futura $\mathrm{v}$ slovenski jezikovni zgodovini prim. Orožen 2003: 20, 25). 
razlik prihaja zaradi doslednosti navajanja predlogov. Npr.: Als denn kanft $d u \boldsymbol{z} \boldsymbol{u}$ fünd / tod vnd Teuffel fagen (LH 1566: II,Vb) - Tedaj ti morefh kgreihu, $\boldsymbol{k}$ 'Smerti inu k'Hudizhu rezhi (TPo 1595: II,7).

3.3 Skladenjske preureditve. Na dobro poznavanje vsebine ter izraznih možnosti izhodiščnega in ciljnega jezika kažejo tiste skladenjske preureditve, ki ne spreminjajo informativnosti besedila. Obstajajo pa tudi take, ki kažejo na prevajalčev zavesten poseg v vsebino: običajno s podomačevalnimi, ponazarjalnimi ali dopolnjevalnimi razširitvami.

3.3.1 V prvo skupino npr. spada preureditev zaporedja delov povedi: Vnd wir find die aller ellendeften menfchen / So wir allein in difem leben auf Chriftum hoffen (LH 1566: II,III) - Aku my le vletim lebni na Chriftufa vupamo, taku fmo my ty nar reunifhi mej vfemi zhloveki (TPo 1595: II,3). V navedenem zgledu sta sestavini pogojnega podredja $\mathrm{v}$ nemški predlogi in v slovenskem prevodu nasprotno razvrščeni.

3.3.2 Jezikovnosistemske narave je tudi različno izražanje zanikanja: v nemščini z ločeno nikalnico, v slovenščini z dvema - z ločeno, besedno izraženo, in s stično pisano nikalnico. Npr.: 1. Solt denn vns folches nit erweychen / das wir [...] nicht fo vnter einander verachteten vnd neydeten (LH 1566: I,XXII) - Ter ne imejlu bi nas takovu omezhiti, de bi my [...] fe nikar taku mej fabo neferrahtali inu ne nydali? (TPo 1595: I,35); 2. Warum die Kirch kein weltlichen zwang oder gewalt hab (LH 1566: III,LXXXIII) - Sakaj ta Cerkou obeniga pofvitniga permorovainja ali oblafti nejma (TPo 1595: III,142); 3. So es hören vnd wiffen / vnd doch nicht achten (LH 1566: I,XXIIb) - kateri je poflufhajo inu vejdo, inu vfaj tu fa nifhter ne fhtimajo (TPo 1595: I,37). Prevod hkrati kaže, da se kot prevodne ustreznice pogosto uporabljajo v rabo trdno vrasle prevzete besede, ki jih domače sopomenke niso uspele izpodriniti.

3.3.3 Med nadomestitve, ki so pogojene z različnostjo nemščine in slovenščine, spadajo zamenjave nedoločnega zaimka man, ki najpogosteje nastopa s pomenom splošne veljavnosti, s konkretnejšimi poimenovanji. ${ }^{27} \mathrm{~V}$ Trubarjevem jeziku ga najpogosteje zamenjujejo: množinski samostalnik ljudje, osebni zaimek mi, nedoločni zaimek eden itd. ${ }^{28}$ Npr.: 1. Got fol man dancken für die groffe ehre / das er menfch ift worden (LH 1566: I,XIX) - Ludje imajo Boga sahvaliti sa to veliko zhaft, de je on zhlovik poftal (TPo 1595: I,31); 2. Darumb ifts hoch von nöten / das man Gott von hertzen bitte (LH 1566: I,XXVI) - Satu je onu vissoku potreba, de my Boga is ferza pro/simo (TPo 1595: I,42). Tovrstne nadomestitve so zelo pogoste tudi pri robnih opombah, saj je z vsebinsko shematizacijo, v katero spada tudi splošni osebek, odprt prostor zanje: Wie man fich menfch werdung Chrifti tröften fol (LH 1566: I,XXIb) - Koku bi fe ludje tiga zhloveftva Chriftufeviga imejli trofhtati (TPo 1595: I,34). Poziv, izražen z obliko za drugo osebo, je Trubar usmeril na nedoločno

${ }^{27}$ Prim. Helbig - Buscha 1996: 259-260.

${ }^{28} \mathrm{O}$ načinih izražanja splošnega vršilca dejanja v slovenskem knjižnem jeziku prim. Toporišič 2000: 357, 606. 
tretjo osebo: Man fehe Bapft (LH 1566: I,XXVII) - Pogledaj eden na Papefha inu Shkoffe (TPo 1595: I,44). Zamenjavo utrjujejo ponovitve. Premik glede načina izražanja osebka lahko spremljajo tudi druge prevodne razlike, kakršna je zamenjava prislovnih določil: prislovnega določila načina (langfam) s prislovnim določilom časa $(\mathrm{ka} / \mathrm{nu})$, ki hkrati zaobsega razmerje med vzrokom in posledico: da wirt mans langfam thun (LH 1566: II,V) - tukaj ga bodo ludje kafnu fturili (TPo 1595: II,6).

3.3.4 Lutrova in nadomestna Trubarjeva prislovna določila kraja se neredko razlikujejo po prislovni sestavini, kar razodeva različno predstavo glede usmerjenosti dejanja, npr. prostorsko proti površinski. Npr.: 1. wie Chriftus Iefus Gottes Son / in dife welt geborn fey (LH 1566: $\mathrm{I}, \mathrm{XXb}$ ) - koku je Chriftus Iefus Boshy Syn, na leta Svejt rojen (TPo 1595: I,33); 2. Denn fo gehets in der welt (LH 1566: I,XXVIII) Sakaj taku onu gre na tem svejtu (TPo 1595: I,45). Razlika ostaja, četudi se menjajo vprašanja, ki se nanašajajo na mesto ali prostor dogajanja: kje? oz. kam?

V številnih drugih primerih se prevoda kljub pomenski iznačenosti prislovnega določila kraja pogosto razhajata po predložni vezavi, značilni za prevodno soočana jezika. Npr.: 1. das droben zur rechten Gottes ift (LH 1566: I,XXIIb) - kateru je osgoraj na Defnizi Boshy (TPo 1595: I,36); 2. Derhalb mögen wir [...] von hertzen bitten (LH 1566: I,XXVIb) - Satiga volo moramo [...] is ferza profsiti (TPo 1595: I,43). Na skrb za doseganje jasne predstave z jezikovnimi sredstvi kaže tudi Trubarjevo nizanje možnih predložnih zvez, ki presega Lutrov predlog: Denn fo die gaben zur hoffart folten (LH 1566: I,XXV) - Sakaj kadar bi ty Daruvi na offert inu Kofferti imejli oberneni biti (TPo 1595: I,40). Nadomeščane in nadomestne predložne zveze, ki so v prevodnem razmerju označevanja izhodišča in cilja glagolskega dejanja, so značilne za oba jezika. V nakazani smeri se pogosto izmenjujejo.

$\mathrm{Z}$ različnimi predložnimi zvezami so izražena tudi prislovna določila načina: das wir von hertzen einander liebeten (LH 1566: I,XXIIb) - de bi my is ferza edan tiga drusiga lubili (TPo 1595: I,36).

(1) Nekaj prevodno opravljenih skladenjskih preureditev ima tudi besednovrstne posledice. Priredno zvezo prislovnih določil načina iz Lutrove postile npr. v Trubarjevem prevodu nadomešča besednovrstno nepoenoten niz, ki ga sestavljata zveza rad trpeti - rad je po novejši slovenski jezikoslovni teoriji (Toporišič 2000: 412; Žele 2004: 37) povedkovnik -, in biti potrpežljiv: das leydet er vmb Gottes willen gern vnd gedultig (LH 1566: I,XVII) - tu terpy on sa Boshjo volo rad, je poterpe/hliv (TPo 1595: I,28).

3.3.5 Med pogosteje zaznavne spremembe skladenjskega značaja spada nadomeščanje premega govora $\mathrm{z}$ odvisnim. Slednji je praviloma posredovan $\mathrm{v}$ predmetnem odvisniku, ki ga napoveduje glagol rekanja, uvaja pa veznik de (1. zgled); enako tudi v primeru, kadar je kot ločilo, ki napoveduje premi govor, ohranjeno dvopičje (2. zgled). Npr.: 1. Vnd ift wol zuuermuten / ob man fchon gefagt hat: Es fey ein jung weyb im Küftall gelegen (LB 1566: I,XIX) - Inu fe more dobru verovat, Aku fe je lih pravilu, de je ena mlada shena vKrauvji fhtali leshala (TPo 1595: I,30-31); 2. Im Bapftum hat man ein Hiftorien gefagt: Es Sey der Teuffel auff ein zeit in die

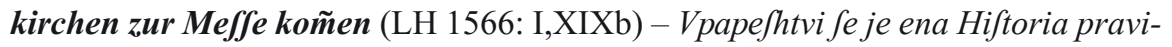
la: De je ta Hudiz na en zhafs v'Cerkou kMafhi prifhal (TPo 1595: I,31). 
3.3.6 V sklop skladenjskih preureditev poleg številnih že obravnavanih razlik spadajo tudi pogosta besednoredna razhajanja, ki so neredko sestavni del besednoredne urejenosti širše skladenjske enote, bodisi stavka ali povedi. Npr.:

\begin{tabular}{|l|l|l|}
\hline $\begin{array}{l}\text { Luter (LH 1566: } \\
\text { III,LXXVII) }\end{array}$ & $\begin{array}{l}\text { Auff das nun wir für } \\
\text { folchem vns hüten lernen / }\end{array}$ & $\begin{array}{l}\text { wöllen wir jetzund folches fchönes Lied } \\
\text { von wort zu wort für vns nemen }\end{array}$ \\
\hline $\begin{array}{l}\text { Trubar } \\
\text { (TPo 1595: III,131) }\end{array}$ & $\begin{array}{l}\text { De fe my vhe pred tako- } \\
\text { vim vuzhimo varovati, }\end{array}$ & $\begin{array}{l}\text { taku my hozhmo fdaj takovo leipo } \\
\text { Peifsen od befséde do befsede pred nas } \\
\text { vseti }\end{array}$ \\
\hline
\end{tabular}

(1) Razlike se kažejo glede stave osebnih in povratnih zaimkov v odnosu do povedka (v slovenščini stoji osebek v glavnem stavku pred povedkom, v nemščini za njim), glede morfema se ob povratnih glagolih itd. Npr.: Mein Geift [...] erfrewet fich auch in Gott meinem Heyland (LH 1566: III,LXXVIIb) - Moj Duh [...] fe vessely tudi vBugi mojmu Isvelizharju (TPo 1595: III,132); Nun fehen wir / das (LH 1566: III,LXXXIIb) - Nu taku my vidimo, de (TPo 1595: III,141). ${ }^{29}$ Razlike se ohranjajo tudi v primeru stilno zaznamovane intonacije, ki ima za posledico spremembo ustaljenega zaporedja členov naslonskega niza.

(2) Primerjava odkriva številne primere neujemalne stave naklonskih glagolov, ki zahtevajo ob sebi povedkovo določilo v obliki nedoločnika: v Trubarjevem prevodu pogosto stojijo pred njim, v Lutrovi predlogi za njim. Npr.: Das er alfo / als vnfer Herr für vns tretten / vnd des Teuffels feind / aber vnfer Herr vnd erlöfer fein wölle / der mich vnnd dich für das feine anfprechen / vnd als die feinen vom teuffel abfordern wölle / vnd jm fagen (LH 1566: I,XXIIIb) - De on taku, kakor nafh GOSPVD, hozhe, sa nas ftopiti tiga Hudizha Sovrafhnik, nafh pak GOSPVD inu Odréfhnik biti, mene inu tebe sa tu fvoje Jposnati, inu kakor te fvoje od Hudizha terjati, inu knjemu rezhi (TPo 1595: I,38). ${ }^{30}$

(2a) Precej spremenjeno je tudi zaporedje sestavin kalkirano prevedenega nemškega ločljivo sestavljenega glagola na koncu vprašalnega stavka. Npr.: difer edler / tewrer fchatz gehet mich nit an? (LH 1566: I,XXIII) - leta Jhlahtni, dragi shaz mene an ne gre? (TPo 1595: I,37).

(2b) Dogaja se, da je Trubar namesto zveze pomožnega glagola in nedoločnika uporabil oz. uporabljal polnopomenski glagol: Solches Heylands / laffen fich die groffen Herrn zu Ierufalem beduncken (LH 1566: I,XXV) - Takoviga Isvelizharja, fe ty veliki Gofpudje vIeruslemi fdee (TPo 1595: I,41). ${ }^{31}$

${ }^{29}$ Na tovrstne Trubarjeve besednoredne oddaljitve od prevodne predloge je opozoril že Raecke, ki meni, da bi lahko bile posledica Trubarjeve izbire ali odraz splošne slovenske govorne rabe (Raecke 1995: 408).

${ }^{30} \mathrm{Ob}$ Trubarjevih besednorednih premikih naklonskih glagolov Raecke opozarja, da je bila z njimi pogosto zabrisana prvotna funkcionalna dvojnost stave, saj je Luter s položajem modalnega glagola pred nedoločnikom označeval modalnost enega dejanja, z zapostavljeno stavo pa modalnost povezanega niza dejanj (Raecke 1995: 410-411).

${ }^{31}$ V zgledu uporabljeni glagol zdeti se sicer izkazuje obe rabi: poleg polnopomenske tudi nepolnopomensko, kadar ob sebi zahteva povedkovo določilo (prim. SSKJ 5: 846-847). 
3.3.7 Med prevodne svoboščine, ki jih izkazuje tudi Trubarjeva Hišna postila, spada sprememba naštevalnega zaporedja. Do slednjega pogosto prihaja pri dveh omenjanih osebah oz. tedaj, kadar zaporedje omemb ne vzpostavlja logično utemeljene hierarhije, ki bi lahko izzivala pričakovane posledice (1. zgled). Če izbira je vrednostno pogojena, mora biti medsebojno razmerje podprto $\mathrm{z}$ drugimi skladenjskimi sredstvi, ki relativizirajo navedbeno zaporedje (npr. z nikalno izključitvijo nesprejemljive možnosti (2. primer)). Npr.: 1. Deñ hie ift niemand / der Kind oder Mutter etwas leyhen [...] wolt (LH 1566: I,XIX) - Sakaj letukaj nikogar nej, kateri bi Materi ali ditetu hotel kaj po/soditi (TPo 1595: I,30); 2. Sintemal er nicht ein Engel / fonder ein menfch worden ift (LH 1566: I,XIXb) - Potehmal je on en zhlovik, inu nikar en Angel postal (TPo 1595: I,31); 3. das man erftlichen die Hiftorien [...] fasfe vnd wiffe (LH 1566: II,II) - de ludje narpoprej to Hiftorio [...] vejdo, inu nio famerkajo (TPo 1595: II,1).

3.3.8 Oblikoslovnega značaja je tudi Trubarjevo spolsko prilagajanje povedka členom sestavljenega osebka. Namesto ene oblike pri Lutru sta pri Trubarju navedeni dve: wo uns ein lieber freund / Weyb / Kind etc. Mit todt ift abgangen (LH 1566: II,CLXXXIII) - kadar je nam en lub priatel, Shena, Déjte, \&c. vmerl ali vmerlu (TPo 1595: II,309).

4 Blizu sklopa jezikovnosistemsko pogojenih besednih zamenjav so tudi prevodni posegi v stalne besedne zveze.

4.1 Frazemi iz Lutrove predloge so bili poseben prevodni izziv za Trubarja. Praviloma jih je nadomeščal s pomensko neposrednejšo, nazornejšo predstavitvijo, neredko pa jih je le sestavinsko prevajal ali delno podomačeval. Npr.: 1. das wir von hertzen auch würden andern leuten gern helffen vnd dienen / ob es vns gleich fawer würde (LH 1566: $\mathrm{I}, \mathrm{XXb}$ ) - de bi my is ferza tudi drugim ludem radi pomagali, inu flushili, aku bi nas tu lih tefhku ftalu (TPo 1595: I,33); 2. auff den hat er ein aug (LH 1566: III,LXXIX) - na tiga on gleda (TPo 1595: III,134); 3. derhalben Chriftus ftets mit jnen muß zи har ligen (LH 1566: III,LXXXb) - sa tiga volo Chriftus veden nym more vlafseh leshati (TPo 1595: III,137).

S sopomenskimi pari ali pari, pri katerih eden izmed členov opravlja razlagalno oz. dopolnilno vlogo, so neredko nadomeščeni in predstavno približani tudi frazemi. Npr.: 1. Es hat nit not mit mir (LH 1566: I,XX) - Ieft ne maram inu fe nifhter ne kumram (TPo 1595: I,32); 2. Man plagt / dringt vnnd treybt fie fo lange / das jhnen die augen vbergehen (LH 1566: II,CLXXXIII) - ony bodo taku dolgu martrani, drengani inu resshaleni, de Se plazhejo inu jokajo (TPo 1595: II,310). Zadnja zamenjava je večkrat ponovljena. Manj izrazit nemški frazem je mestoma nadomeščen z bolj znanim domačim: 1. die henget vns noch jmmer an (LH 1566: I,XXVII) - ta nam fhe vfelej vkofhi tizhy (TPo 1595: I,44); 2. das laufft vnferm Herren Gott in Jpieß / vnnd muß gedemütiget werden (LH 1566: III,LXXIXb) - tu tezhe nafhimu GOSPVDV Bogu vfhpeis, ali fupar oftein berza, inu more ponishanu biti (TPo 1595: III,135); 3. nicht in wind hin lebe (LH 1566: II,CLXXXII) - nikar 
tja nemarnu ali vdan ne shivejo (TPo 1595: II,308). Tudi na tem področju je kot nadomestilo lahko uporabljena prevzeta struktura, posvojena $\mathrm{z}$ dolgotrajno rabo in tudi v postili večkrat ponovljena. Npr.: das du darunter hetteft müffen zu boden gehen (LH 1566: II,IIIb) - de bi ti pod nymi bil moral konez vseti (TPo 1595: II,3). ${ }^{32}$ Ustaljeno zvezo gantz vnd gar 'popolnoma' je Trubar nadomeščal z opisnim približkom: Mit folchen rofen wil Gott von vns gefchmückt fein / das wirs jm gantz vnd gar geben (LH 1566: I,XXVIIb) - Stakovimi rofhami de gofpudi Bogu famimu to zhaft damo, hozhe Bug od nas snafhen biti (TPo 1595: I,45).

4.2 Jezikovno polarizirane so tudi ustaljene besedne zveze. Npr.: am grünen Donnerftag (LH 1566: II,II) - na veliki zhetertik (TPo 1595: II,1); am ftillen Freytag (LH 1566: II,IIIIb) - na veliki petak (TPo 1595: II,6). Razlikovalni element je v obeh primerih pridevnik. Podobno razhajanje se kaže tudi pri drugih prilastkovnih zvezah. Npr.: 1. Deñ folches ift nur ein zeytliche ehr geweft (LH 1566: III,LXXXI) - Sakaj takovu je le ena potelefna zhaft bila (TPo 1595: III,138); 2. An jenem tag aber wirt nicht mehr glauben / Sondern fehen (LH 1566: II,V) - Na unim Svetu my tiga ne bodemo vezh verovali, temuzh je bomo vidili (TPo 1595: II,6). Isto velja tudi za druga ustaljena poimenovanja. Npr.: von nu an werden mich felig preifen alle kindes kind (LH 1566: III,LXXVIII) - odfehmal bodo mene vfi roduvi sa isvelizhano derfhali (TPo 1595: III,133). Različna izbira kaže na tradicijo, vezano na različne sredine.

4.2.1 Zdi se, da je Trubar pridevniško sestavino iz ustaljene prilastkovne zveze občasno opustil prav zato, ker je bila zaradi ustaljenosti uzaveščena in zato pogrešljiva. Npr.: der leydige Teuffel (TH 1566: I,XXIIb) - ta Hudizh (TPo 1595: I,36). Zvezo namreč zelo pogosto nadomešča delno pleonastična zali hudič. ${ }^{33}$

4.3 Bolj ali manj razhajajo se tudi pritrjevalni vzkliki, vzeti iz govorjenega jezika. Npr.: Gott hab ewig lob (LH 1566: II,IIII) - Bogu bodi vekoma hvala (TPo 1595: II,4). Med navedenima zgledoma je glagolsko-vezavna razlika. Prav tako niso redki primeri prevzemanja uveljavljenih rekov, ki ne kažejo izrazitejše vraslosti v mladi slovenski knjižni jezik. Npr.: Ia den Teuffel auff deinen Kopff (LH 1566: III,LXXVIIb) - Ia Hudizha na tvojo glavo (TPo 1595: III,132).

4.3.1 Tudi neposredni nagovori, ki poglabljajo stik med govorečim in naslovnikom, zrcalijo ustaljeno rabo, ki v nemščini in slovenščini ni nujno enaka: Lieber (LH 1566: I,XXIII) - Lubi Brat (TPo 1595: I,37). Razlika obstaja tudi pri rabi vsakdanjih obrazcev, npr. glede uporabe pozdravnih formul: Iefus [...] sprach: Seyd gegrüffet (LH 1566: II,VIb) - Iesus [...] je djal: Sdrave bodite (TPo 1595: II,8).

${ }^{32}$ Z zvezo konec vzeti je prezrcaljen nemški frazem ein Ende nehmen (prim. Duden 1998: 177).

${ }^{33} \mathrm{O}$ pomenu nemške prilastkovne zveze leydige Teuffel in njene slovenske ustreznice zali hudič, ki se v TPo 1595 pojavlja kar desetkrat, prim. Merše 2009: 286-287. 
- 4.4 Izbira opisa namesto (manjkajočega) enobesednega izraza je splošno znana prevodna možnost. Nadomestitev lahko poteka obojesmerno. Npr.: wir faulen fchelmen (LH 1566: I,XX) - my lini sanikerni ludje (TPo 1595: I,32); das jie mögen luft haben in vnluft / vnd fingen / wenn der Teuffel zornig ift (LH 1566: I,XXVIIIb) - de bi mogli vfhalofti, vefseli biti inu peiti, kadar fe ta Hudizh ferdy (TPo 1595: I,46); So dich nu die fünde anfechten wil / vnd das gewiffen dich betrüben (LH 1566: II,Vb) - Inu aku vfhe tebe hozhe ta greih vftrafhiti, ta veift shaloftniga fturiti (TPo 1595: II,7); vnd wird dich jrr machen (LH 1566: III,LXXIX) - inu bode tebe fmotila inu omamila (TPo 1595: III,135); Selig findt / die da leyd tragen (LH 1566: II,CLXXXI) - Isvelizhani fo ty, kateri shalujo (TPo 1595: II,306); Selig findt die fridfertigen (LH 1566: II, CLXXXI) - Isvelizhani fo ty, kir myr dellajo (TPo 1595: II,306).

Tudi možnost enostranske izbire glagola, ki izraža dejanje, ali glagola oz. opisa, s katerim je izraženo stanje, je pogosto udejanjena, kar prav tako kaže na univerzalnost postopka. Npr.: Gott gebe das wirs verftehen / zu hertzen nemen / vnd Gott dafür danckbar fein (LH 1566: I,XX) - Bug daj, de bi je my saftopili, kferzu vseli, inu Boga satu hvaliti (TPo 1595: I,33). Podobno še widerftand thun $\rightarrow$ suparftati itd.

4.5 Strukturna neujemalnost Lutrove predloge in Trubarjevega prevoda je večkrat posledica enostranske izbire predložne zveze in sopomenskega enobesednega izraza, npr. pridevnika: Zum andern / follem wir das Exempel Chrifti fleiffig anfehen (LH 1566: I,XX) - Hdrugimu, imamo my na ta Exempel Chriftufou s'flifsom pogledati (TPo 1595: I,33).

4.6 Trubar je vsebinsko enakovreden prevod pogosto dosegal z drugimi ubeseditvenimi sredstvi, npr.: 1. Aber vnter den Chriften fols nit fo fein (LH 1566: I,XXVIII) - Ampak mej temi Karfzheniki ima drigazhi biti (TPo 1595: I,46); 2. die faffen vnfers Herrn Gottesdienft fehr fein (LH 1566: I,XXVIII) - ty sapopadejo Boshye opravilu cilu lipu (TPo 1595: I,46). Prvi zgled kaže na izbiro različno izražene sopomenske možnosti: nit fo 'ne tako' $\rightarrow$ drugače. V drugem zgledu je Trubar racionalno opustil pleonastični del zveze, s čimer ni okrnil obvestilnosti povedi. Obvestilno izenačenost je dosegal tudi z izbiro trdilne namesto nikalne različice: Aber ift es nit ein jammer vber allen jammer (LH 1566: III,LXXXIIIb) - Ali en jamer je inu reva zhes vus jamer (TPo 1595: III,142).

4.7 V številnih primerih je s prevodnim ekvivalentom udejanjena tudi pomenska sprememba. Drugačne vsebinske poudarke oz. aktualizacijo drugih pomenskih sestavin praviloma omogoča zamenjava ene tvorjenke z drugo. Npr.: 1. Solches bild [...] follen wir anfehen / mit eim vnzweyffelhafftigen hertzen (LH 1566: II,IIb) Takou Pild [...] imamo my pogledati, fenim vernim ferzom (TPo 1595: II,2); 2. der Engel [...] den ftein vom Grabe hinweg gethan habe (LH 1566: II,IIb) - je ta Angel [...] ta kamen od Groba odvalil (TPo 1595: II,2). V 1. zgledu je namesto poudarka 'srce, ki ne dvomi' aktualizirana pomenska sestvina vernosti. V 2. zgledu pa je s Trubarjevo izbiro glagola odvaliti pri odstranjevanju kamna aktualiziran tudi način 
odstranitve: premikanje z valjenjem. Slovenski prevod je v tem primeru za omenjeno pomensko sestavino bogatejši in hkrati tudi nazornejši.

4.7.1 V sledečem primeru je vzrok za različen prevod prilastka lahko zavestna izbira ekvivalenta, ki se neredko hote odmika od prevodne predloge, ali pa napačno branje (fchendliches namesto dejanskega /chedliches): was für ein fchedliches gifft folche hoffart fey (LH 1566: III,LXXXIIb) - kaj sa en framoten ftrup je takova offert (TPo 1595: III,141).

5 Eno izmed značilnosti Trubarjevega prevoda predstavljajo tudi vsebinske podomačitve in prilagoditve, prav tako opravljene $\mathrm{z}$ namenom, da bi bila vsebina lažje dojemljiva in v čim večji meri razumljena. V sklop tovrstnih sprememb spadajo zamenjave Lutrovih omemb Nemčije oz. Teutfchland, tj. »nemške dežele«, s kranjsko deželo, npr. v vsebinskooznačevalni robni opombi: Teutfchem land wirds vbel gehen (LH 1595: II,CXVIb) - Krainfki Desheli hudu pojde (TPo 1595: II,194). Poleg primerov podomačevanja in prilagajanja obstajajo tudi primeri ponazarjalne širitve z omembami novih dežel. Npr. gleych wie heutigs tags Deutfchland fich grewlich verfündiget / mit manchfeltiger verfolgung des worts vnd feiner diener (LH 1566: II,CXIIII) - raunu kakor na ta danaJhni dan Je Krainfka Nemfhka inu druge deshele grosovitu pregrefhe, s'mnogoterim pregainenjem te befsede inu njegovih slushabnikou (TPo 1595: II,191).

5.1 Poleg ponazoritvenih omemb pokrajin so namesto krajev, znanih nemškim bralcem in poslušalcem in namenjenih oblikovanju zanje potrebne predstave, navedeni tudi kraji, poznani naslovnikom Trubarjevega prevoda. Npr.: Es ift ein eben weite reife von Nazareth auß Galilea / gen Bethlehem / ja fo weit als auß Sachfen in Francken / wo nit weiter (LH 1566: I,XIX) - Onu je reis ena dolga raifha ali pot od Nazareta is Galilee, vBetlehem, ja taku delezh, kakor od Lublane do nemfhkiga Graza, aku nikar dajle (TPo 1595: I,30). V ponazoritev sta bili nadomestno vpleteni tudi osrednjeslovenski reki, znani večini naslovnikov: wenn $d u$ fchon das hauß vol gülden / vnnd die Elbe oder der Rein flüffe mit golde / vnd were dein eygen / was köndt folches dich helffen / wenn fonft nichts (LB 1566: II,CXXXVI) - kadar bi ti vshe lih to hisho polno flatih imel [...] inu ta Lublaniza ali Sava bi tekla s'flatom, inu bi bilu ve tvoje laftnu, kaj bi tebi moglu takovu pomagati (TPo 1595: II,228).

5.2 Večjo predstavljivost vsebine je Trubar hkrati dosegal na več načinov. Geografsko podomačitev, ki jo predstavlja nadomestitev Teut/chland 'Nemčija' z opisnim poimenovanjem krainfka defhella, je dopolnil z nadomestno izbiro priljubljenih cerkvenih pesmi, ponazorjenih s prvim verzom. Namesto nemške katoliške pesmi, ki se pričenja z verzom Ein kindelein fo löbelich, je z verzom Ta dan je v/iga veJselja, označil pesem, ki so jo radi peli njegovi rojaki. Npr.: man hat auch jerlich durchaufinn Teutfchland diffchön Chriftlich Lied / Ein kindelein fo löbelich / allenthalb gefungen / vnnd fingets noch (LB 1566: I,XXVb) - onu fe je tudi vfaku leitu fkusi v'krainfki defhelli leta leipa Karfzhanfka Peifan, Ta dan je vfiga veJselja, 
- poufod pejla, inu njo fhe pojo (TPo 1595: I,41-42). Enako zamenjavo kot božična je doživela tudi velikonočna pesem, v slovenščini kot zvočno rimani kirielejson: Als da wir fingen: Chrift ift erftanden / von feiner marter allen / des follen wir alle fro fein / Chrift fol vnfer troft fein (LB 1566: II,IIIb) - Kakor ker my pojemo: Iefus ta je od Smerti vftal. Vragu je to glavo fteptal, Obtu fe vefselimo, Inu Boga hvalimo, Kyrieleifon (TPo 1595: II,4). Da gre za isto pesem, v nadaljevanju kaže isto latinsko besedilo.

5.3 Vsebinske ponazoritve je Trubar dosegal tudi s samoinciativno dodanimi, obvestilno zgoščenimi robnimi opombami, ki jih je kot večji vsebinski preglednosti namenjeno obvestilno dopolnilo vešče obvladal. Npr.: Ta Evangeli, ta zhlovefka pamet ne vej (TPo 1595: I,36). ${ }^{34}$ Trubar je opombe pogosto dodajal. Oblikovane so kot zloženi ali nezloženi stavki oz. povedi. Npr.: Kateri Iefufa prou vferci ima, tiga obena reva Jhaloftniga fturi (TPo 1595: I,46); Verne obena fhaloft ne premaga (TPo 1595: I,46). ${ }^{35}$

5.4 Svobodnejši prevod izkazujejo tudi številna druga mesta, npr. tista, na katerih splošne pojme nadomeščajo konkretna poimenovanja. Npr.: fo müß es auch alfo fein / oder es werde ein lauter confufio / vnd vnordnung fein (LH 1566: III,LXXXIII) - taku mora tudi taku biti, ficer bode vfe hudu preobernenu inu fmeiha vrednu (TPo 1595: III, 142-143). Zanimiva je nadomestitev zveze anders vnkrauts z druge lulke. Npr.: Gleych wie ein acker vnrein ift / wenn er vol ftein / vol difteln vnd dorn / vnd anders vnkrauts ift (LH 1566: II,CLXXXV) - Raunu, kakor je ena Nyva nezhifta, kadar je polna kameinja, polna ofsata inu ternja, inu druge lulke (TPo 1595: II,314).

\section{Izbor različnih stilemov}

6.1 Besedni izbor je pogosto enostransko stilno pogojen. Običajno je z nizanjem glasovno usklajenih izrazov učinkoval Luter, ${ }^{36}$ saj je oblikoval opazne stavčne zaključke, ustvarjal notranjo rimo v povedi itd. Trubarju tovrstnih kombinacij in učinkov s prevodno predlogo usmerjana in na ekvivalente, ki so bili na voljo v slovenskem jeziku, vezana izbira ni vedno omogočala. Npr.: 1. Da die andern braffen,

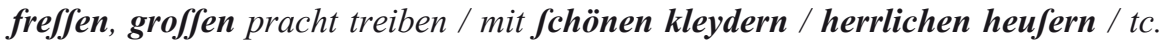
(LH 1566: I,XIX) - kadar drugi pianzhuyo, Jhro, veliku pranganje imaio, slepim gvantom, szhaftitimi hifhami, \&c. (TPo 1595: I,31); 2. das fchier niemand ein augenblick ficher ift / weder des leides noch des guts halb / welches alles in gfahr fchwebet vnd webet (LH 1566: I,XXI) - de Jkoraj nihzhe en hip nej Jhiher, ni sa tiga

${ }^{34}$ Glede na današnjo normo nase opozarja tožilniška vezava, ki ni tipična za zanikanje.

${ }^{35}$ Metodologija Trubarjevega prevzemanja, prevajanja, oblikovanja in spreminjanja opomb bo predstavljena $\mathrm{v}$ posebni razpravi.

${ }^{36} \mathrm{~V}$ nemški literarni in jezikovni zgodovini je izjemna stilistična izoblikovanost Lutrovih del splošno priznano dejstvo (prim. Bach 1985: 1443). 
Telefsa, ni sa tiga Blaga ftran, kateru vfe vfarlikofti je inu ftoji (TPo 1595: I,34); 3. Du verfluchter Geift [...] du betreugeft vnd beleugeft fie (LH 1566: I,XXIIII) - Ti prekleti Duh [...] ti ogolufavafh inu oblafhefh nje (TPo 1595: I,39); 4. auffhören mit liegen vnd triegen (LH 1566: I,XXIIIb) - bi nehali od lafh, goluffye (TPo 1595: I,38). Prvi zgled kaže, da je Luter tročlenski niz glasovno podobnih izrazov sestavil iz dveh glagolov in iz tretjega le glasovno podobnega, besednovrstno pa drugačnega člena. Tretji primer kaže, da sta v slovensko ustreznično dvojno formulo povezana priponsko različna glagola, kar ruši vtis glasovne harmonije. Zadnji primer pa kaže, da je Trubar namesto glasovno ujemajočih se glagolov iz Lutrove predloge uporabil samostalnika, ${ }^{37} \mathrm{ki}$ si sledita za vejico, torej vezniško nepovezano. Prav z dvojnimi formulami je Trubar neredko kompenziral izostanek glasovno učinkovitih povezav: Wo fie aber fich nicht fo helt / vnd jr macht zu eygnem pracht [...] mißbrauchen wil (LH 1566: III,LXXXIII) - Kadar fe ona pak nikar taku ne dershy, inu hozhe fvojo muzh inu Oblaft k'laftnimu prangainju [...] krivu inu hudu nuzati (TPo 1595: III,142).

Tudi glasovno-oblikovne poenotenosti, ki jo Luter npr. ustvarja $\mathrm{z}$ enakimi sklonskimi končnicami priredno nanizanih prilastkov, Trubar ni mogel vedno dosegati, saj mu jo je poleg neenake tvorjenosti ali različnega izvora prilastkov preprečevala tudi neustaljena raba določnih pridevniških oblik in posledično priredno povezovanje določnih in nedoločnih oblik. Npr.: WEil das heutige Feft / den tröftlichen vnd frölichen Artickel vnfers Glaubens vns fürhelt (LH 1566: II,IIa) - Kadar ta danafhni Prasnik, ta trofhtliv inu veffeli Articul nafhe vere nam naprej dershy (TPo 1595: II,Ia). Na nekaterih mestih pa je Trubarju uspelo v dvojno formulo povezati zvočno podobna glagola in na tak način stopnjevati stilno učinkovitost prevoda: da follen fie gar fein / fpricht fie / anlauffen (LH 1566: III,LXXIX) - taku fe ony morajo, pravi ona, saplefti inu sabrefti (TPo 1595: III,135).

6.1.1 Notranje glasovno ujemanje ustvarja tudi nizanje nasprotnih pojmov, ki jih zastopata izhodiščno poimenovanje in njegovo nasprotje v Lutrovi Hišni postili ter poimenovalno različne ustreznice $\mathrm{v}$ slovenskem prevodu. Npr. es gibt weder luft noch vnluft (LH 1566: I,XXI) - onu ne da ni ne vefselia ni Jhalofti (TPo 1595: $\mathrm{I}, 33)$.

6.2 Na Trubarjevo zavedanje možnosti stilnega učinkovanja z nizanjem ekvivalentov pa zelo jasno kažejo številne dvojne in trojne povezave, za katere Lutrova predloga ni dajala osnove. Dodatno učinkoviti so pari glasovno podobnih ustreznic. Npr.: begegnet der Herr Chriftus der Magdalena inn der geftalt eines Gertners (LH 1566: II,IIb) - je frezhal GOSPVD Chriftus te Magdalene, vfhtalti eniga kopazha, Gartlerja ali Vertarja (TPo 1595: II,2). Tričlenski niz tudi pomensko razširja predstavo, saj vanj niso vključene popolne sopomenke.

Na drugih mestih je Trubarju uspelo enakovredno nadomestiti premišljeno urejene in glasovno učinkovite dvodelne povedi iz prevodne predloge s preureje-

${ }^{37}$ Prvi samostalnik je izglagolski, drugi pa po izsledkih etimologije (prim. Bezlaj 1976: 159) izsamostalniški ( goljuf $\rightarrow$ goljufija). 
- nimi strukturami. Opaznost in ritmično učinkovitost jim je - enako kot pri Lutru [- - zagotavljala enaka razporejenost stavčnih členov in ponavljanje elementov. Npr.: Die Engel dürffen fein nicht / Die Teuffel wöllen fein nicht (LH 1566: I,XXIII) - Ty Angeli njega ne potrebuio, Ty Hudizhi njega ne hote (TPo 1595: I,37). Trubarjevo besednoredno preurejanje besedila iz Lutrove predloge je mestoma pripeljalo do

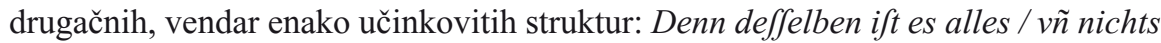
mein (LH 1566: III,LXXVII) - Sakaj tiga iftiga je vfe, inu moje nifhter (TPo 1595: III,131). V navedenem primeru je Lutrovo hiazemsko ureditev zamenjala Trubarjeva podvojitev vzorca.

6.3 Tudi Lutrovemu prestopu v nižji pogovorni jezik z glasoslovno močno preoblikovanim (okrnjenim) besedjem, ki je vezano na vnaprej napovedano rečenico, razširjeno med preprostimi ljudmi, Trubar ni sledil: Das gemein fprichwort ift vnter vnfern burgern vñ bawrn: Wat: Ick heb ock noch twe penning to vertern (LH 1566: III,LXXVIIa) - Ta gmain perpuvid je mej nafhimi purgary inu kmetizhi: Haj Ieli imam tudi fhe dva Vinarja ferzerati (TPo 1595: III,131). Vzrok za opustitev priložnosti za glasovno barvanje jezika, pogovorno rabljenega v določenem družbenem okolju, je lahko bil v več desetletij trajajočem prizadevanju za enotnejšo podobo mladega slovenskega knjižnega jezika in ne morda $\mathrm{v}$ neobstajanju tovrstnih pogovornih različic ali v Trubarjevem nezavedanju njihovega obstoja. Na zavedanje stilne označenosti odlomka pa jasno kaže enostransko dodani uvajalni medmet.

7 Ob navedenih prevodnih razlikah, ki so bile odkrite s primerjavo večjega števila poglavij iz vseh treh delov Hišne postile, se je treba zavedati, da so številna mesta prevedena člensko, ustreznično in celo besednoredno povsem enako. Za ponazoritev popolne prevodne usklajenosti naj poleg že navedenega zadoščata še dva primera (1. zgled: LH 1566: I,XXII in TPo 1595: I,35; 2. zgled: LH 1566: II,Vb in TPo 1595: II,7.):

\begin{tabular}{|l|l|l|l|l|l|l|l|l|l|l|l|}
\hline 1 & Luter & Die & Engel & find & viel & ein & herzlichere & Creatur/ & denn & wir & Menfchen \\
\hline & Trubar & Ty & Angeli & fo & veliku & ene & zhaftitifhe & Stvari, & kakor & my & zhloveki \\
\hline 2 & Luter & War & ift & es & & & & & & & \\
\hline & Trubar & Reis & je & onu & & & & & & & \\
\hline
\end{tabular}

\section{Viri in literatura}

Ahačič 2007 = Kozma Ahačič, Zgodovina misli o jeziku in književnosti na Slovenskem: protestantizem, Ljubljana: Založba ZRC, ZRC SAZU, 2007 (Linguistica et philologica 18).

Bach 1985 = Heinrich Bach, Die Rolle Luthers für die deutsche Sprachgeschichte, Sprachgeschichte 2, Berlin - New York: Walter de Gruyter, 1985 (Handbücher zur Sprach- und Kommunikationswissenschaft 2.2), 1440-1447. 
Bezlaj 1976 = France Bezlaj, Etimološki slovar slovenskega jezika 1: A-J, Ljubljana: Slovenska akademija znanosti in umetnosti (izd.) - Mladinska knjiga (zal.), 1976.

Duden 1998 = Redewendungen und sprichwörtliche Redensarten, Mannheim idr.: Dudenverlag, 1998 (Der Duden 11).

Helbig - Buscha 1996 = Gerhard Helbig - Joachim Buscha, Deutsche Grammatik: ein Handbuch für den Ausländerunterricht, Leipzig idr.: Langenscheidt Verlag Enzyklopädie, ${ }^{17} 1996$.

LB 1545 (1974) = Martin Luther, Biblia: Das ift: Die gantze Heilige Schrifft Deudsch auffs new zugericht, Wittenberg, 1545, München: Deutscher Taschenbuch Verlag, 1974.

LH 1544 = Martin Luther, Hauspoftill I-III, Wittenberg, 1544, Bayerische Staatsbibliothek, Digitale Bibliothek, Münchener Digitalisierungszentrum. $<$ http:// daten.digitale-sammlungen.de/ db/0003/bsb00030597/images/; http://daten. digitale-sammlungen.de/ db/0003/bsb00030598/images/; http://daten.digitale-sammlungen.de/ db/0003/bsb00030599/images/>

LH 1566 = Martin Luther, Haußpoftill I-III, Nürnberg, 1566. <http://www.mdznbn-resolving.de/urn/resolver.pl?urn=urn:nbn:de:bvb:12-bsb10144055-7>

Merše 1990 = Majda Merše, Jezikovne spremembe v Trubarjevih prevodih Nove zaveze, v: Razprave drugega razreda SAZU 13 (1990), 163-179.

Merše 1995: = Majda Merše, Kongruenz und Divergenz der Übersetzung von Verben in der Dalmatinschen und Lutherschen Bibelübertragung, v: Ein Leben zwischen Laibach und Tübingen: Primus Truber und seine Zeit, München: Verlag Otto Sagner, 1995 (Sagners slavistische Sammlung 24), 492-510.

Merše 2007 = Majda Merše, Prepoznavnost in značilnosti besedja slovenskih protestantskih postil, Slavistična revija 55 (2007), št. 1-2, 65-84.

Merše 2009 = Majda Merše, Slovenski knjižni jezik 16. stoletja: razprave o oblikoslovju, besedotvorju, glasoslovju in pravopisu, Ljubljana: Založba ZRC, ZRC SAZU, 2009 (Linguistica et philologica 23).

Merše 2010 = Majda Merše, Raba samostalniških manjšalnic v delih slovenskih protestantskih piscev 16. stoletja, Slavistična revija 58 (2010), št. 1, 45-63.

Merše - Novak - Premk 2001 = Majda Merše - France Novak - Francka Premk, Slovar jezika slovenskih protestantskih piscev 16. stoletja: poskusni snopič, Ljubljana: Založba ZRC, ZRC SAZU, 2001.

Muster Čenčur 1998 = Nanika Muster Čenčur, Nemška slovnica po naše, Ljubljana: Cankarjeva založba, ${ }^{7} 1998$.

Novak 2004 = France Novak, Samostalniška večpomenskost v jeziku slovenskih protestantskih piscev 16. stoletja, Ljubljana: Založba ZRC, ZRC SAZU, 2004 (Linguistica et philologica 10).

Orožen 1996 = Martina Orožen, Poglavja iz zgodovine slovenskega knjižnega jezika (od Brižinskih spomenikov do Kopitarja), Ljubljana: Filozofska fakulteta, Univerza v Ljubljani, Oddelek za slovanske jezike in književnosti, 1996.

Orožen 2003 = Martina Orožen, Razvoj slovenske jezikoslovne misli, Maribor: Slavistično društvo Maribor, 2003 (Zora 26). 
Pogorelec 1972 = Breda Pogorelec, Trubarjev stavek, Seminar slovenskega jezika, literature in kulture: zbornik predavanj 8 (1972), 305-321.

Raecke 1995 = Jochen Raecke, »er sich des schwären Wercks /nämlich die Haußpostill D. Martini Lutheri / in die Windische Sprach zu vbersetzen vnderfangen«: »Windisches« in der »windischen Sprach« der Truberschen »Hishna Postilla«, v: Ein Leben zwischen Laibach und Tübingen: Primus Truber und seine Zeit, München: Verlag Otto Sagner, 1995 (Sagners slavistische Sammlung 24), 382-413.

Rigler 1968 = Jakob Rigler, Začetki slovenskega knjižnega jezika, Ljubljana: Slovenska akademija znanosti in umetnosti, 1968 (Dela razreda za filološke in literarne vede 22; Dela Inštituta za slovenski jezik 10.)

Seitz 1995 = Elisabeth Seitz, Govorniško stilno sredstvo ali pomoč pri prevajanju?: dvojično vezniško priredje v izbranih besedilih Primoža Trubarja, Martina Lutra in njunih sodobnikov, Slavistična revija 43 (1995), št. 4, 469-489.

Seitz 1998 = Elisabeth Seitz, Primus Truber - Schöpfer der slovenischen Schriftsprache?, München: Verlag Otto Sagner, 1998 (Slavistische Beiträge 363).

SP 2001 = Jože Toporišič idr., Slovenski pravopis, Ljubljana: Slovenska akademija znanosti in umetnosti - Znanstvenoraziskovalni center SAZU (izd.) - Založba ZRC SAZU.

SSKJ 1-5 = Slovar slovenskega knjižnega jezika 1-5, Ljubljana: Slovenska akademija znanosti in umetnosti (izd.) - Državna založba Slovenije (zal.), 19701991.

Stanovnik 2005 = Majda Stanovnik, Slovenski literarni prevod 1550-2000, Ljubljana: Založba ZRC, ZRC SAZU, 2005 (Studia litteraria).

Toporišič 1992 = Jože Toporišič, Enciklopedija slovenskega jezika, Ljubljana: Cankarjeva založba, 1992 (Leksikoni Cankarjeve založbe: Sopotnik).

Toporišič 2000 = Jože Toporišič, Slovenska slovnica, Maribor: Založba Obzorja, ${ }^{4} 2000$.

TPo 1595 = Primož Trubar, HISHNA POSTILLA, Tübingen, 1595. <http://www. dlib.si/?urn=URN:NBN:SI:DOC-02UIU4RU>

TT 1581-82 = Primož Trubar, TA CELI NOVI TESTAMENT, Tübingen, 1581-1582.

Vidovič Muha 1997 = Ada Vidovič Muha, Tipologija slovenskih ustreznic nemškim zloženkam v Gutsmanovem slovarju, v: Breda Pogorelec (ur.), Jezikoslovne in literarnovedne raziskave: zbornik referatov 6. srečanja slavistov, Celovec - Ljubljana, 1989, Ljubljana: Filozofska fakulteta, 1997, 39-54.

Žele 2004 = Andreja Žele, Povedkovnik v slovenščini, Jezikoslovni zapiski 10 (2004), št. 1, 33-42.

Listkovno gradivo Sekcije za zgodovino slovenskega jezika Inštituta za slovenski jezik Frana Ramovša ZRC SAZU v Ljubljani, zbrano s popolnimi izpisi del slovenskih protestantskih piscev 16. stoletja. 


\section{Trubar's Hišna postila in relation to Luther's original}

\section{Summary}

A comparative analysis of Trubar's translation technique in his Hišna postila (Devotions for the Home) - that is, in his last and most extensive work, which was published nine years after his death - shows not only a close connection with Luther's original, but also many deviations from it. Two types of differences were determined: those conditioned on the differences between German and Slovenian when paired as languages in translation, and the result of the translator's desire to distance himself from the original.

The most apparent differences include translation expansions that were primarily used to make the translation easier to understand and so that the presentation of the content would be appropriately representational. Among these expansions, synonym pairs and polynomial strings stand out in frequency (e.g., regiment $\rightarrow$ Regiment ali regiranje 'reign or rule', Mufica $\rightarrow$ Mufica ali pejtje 'music or signing', fechten $\rightarrow$ fe fehtati inu bojovati 'to fight or battle' etc.). The addition of a synonym (or elements with other sorts of content) created pairs and polynomial strings that differ in terms of part of speech (nominal and verbal strings predominate), as well as regarding the origin of the synonym (the structure borrowed word + native synonym predominates, but other combinations are also possible, such as a string of native synonyms). In contrast to Luther's version, verbal pairs are often arranged in the form of aspectual oppositions or pairs. By frequency of pairing, modal verbs and verbs of speaking stand out (e.g., fie .. .gefagt 'she said' $\rightarrow$ je ona ... govorila inu pravila 'she ... said and told'; er kan 'he can' $\rightarrow$ On . . sna inu more 'he is able to and can').

Trubar added or omitted individual elements based on his own judgment. Several examples show that he omitted more expressive content elements and added, for example, modifiers of circumstance, repeated subjects already mentioned, included objects, and replaced pronouns with more concrete nouns - all in order to keep the basic facts in mind and to sustain the presentation.

The difference between the language of the original and that of the translation is illustrated by departures at various levels of linguistic structure (e.g., at the lexical level, which also includes word-formational structure, and also at the morphological and syntactic levels). For example, in Trubar's translation German nominal compounds are often replaced by typified attributive clauses (e.g., Engelpredig $\rightarrow$ Angelfka Pridiga 'angelic sermon', nothelffer $\rightarrow$ pomozhnik is nadlug 'helper in need'); Trubar reduced the expressional shortcoming through an established style with the inclusion of calqued verbs that are only partly connected to the verbs in the original; impersonal man 'one' is replaced with more concrete designations (e.g., ljudje 'people', $m i$ 'we', eden 'one', etc.); adverbial modifiers of place used in parallel differ regarding the orientation of the action (e.g., in dife welt $\rightarrow$ na leta Svejt 'into this world'), and so on. The linguistic difference also results in many changes in word order and several syntactic changes are the result of Trubar's conscious deviations from the original text: for example, direct speech is often replaced with 
- indirect speech and the textual sequence is often changed. The choice of description [a rather than coinage took place in both directions as a universal narrative option. N Trubar also made the text conceptually closer to readers in Slovenia through geo- $\quad$ graphical adaptation (e.g., Teutfchland 'Germany' $\rightarrow$ kranjska dežela 'Carniola'; he replaced die Elbe oder der Rein 'the Elbe or the Rhine' with the Slovenian rivers Lublaniza ali Sava 'Ljubljanica or Sava'), by citing verses from Slovenian songs, and by including phrasemes and phrases established in Slovenia (e.g., am ftillen - $\quad$ Freytag 'on Good Friday' [literally, 'quiet Friday'] $\rightarrow$ na veliki petak 'on Good - Friday' [literally, 'great Friday']). The expansions and contractions of the text in particular display Trubar's capacity to stylistically shape the text because he skillfully replaced one type of styleme (attested in Luther's original) with others. $\mathrm{He}$ did this effectively, for example, through arrangement in pairs, choosing synonyms formed the same way, phonological correspondence, and other means. 